\title{
Low water stage marks on hunger stones: verification for the Elbe from 1616 to 2015
}

\author{
Libor Elleder $^{1}$, Ladislav Kašpárek ${ }^{2}$, Jolana Š́rová ${ }^{3}$, and Tomáš Kabelka ${ }^{4}$ \\ ${ }^{1}$ Applied Hydrological Research Department, Czech Hydrometeorological Institute, Prague, Czech Republic \\ ${ }^{2}$ T. G. Masaryk Water Research Institute, p.r.i., Department of Hydrology, Prague, Czech Republic \\ ${ }^{3}$ Hydrological Database and Water Balance, Czech Hydrometeorological Institute, Prague, Czech Republic \\ ${ }^{4}$ Prague Regional Office, Department of Hydrology, Czech Hydrometeorological Institute, Prague, Czech Republic
}

Correspondence: Libor Elleder (libor.elleder@chmi.cz)

Received: 30 August 2019 - Discussion started: 7 November 2019

Revised: 8 April 2020 - Accepted: 18 April 2020 - Published: 28 September 2020

\begin{abstract}
This paper deals with the issue of documenting hydrological drought with the help of drought marks (DMs) which have been preserved on dozens of hunger stones (HSs) in the river channel of the Elbe in Bohemia and Saxony. So far, the hunger stones have been regarded rather as an illustration of dry seasons. Our aim was, among other issues, to draw attention to the much greater value of hunger stones and individual dry year marks inscribed on them. Therefore, we wanted to verify their reliability and better understand the motivation of their authors. For this purpose, we used the current extreme drought period of 2014-2019, which allowed detailed documentation of a hunger stone in Děčín, Czech Republic, with marks dating from 1536 to 2003. Thanks to the helpful position of the stones relative to the water gauge, we could compare the measured mark heights to the corresponding water levels. Simultaneously, we have scanned the objects into 3D format so that it is possible to perform a detailed inspection of all the marks, even those that were overlooked during the field survey. A review of scientific and technical literature from the 19th century showed that the marks of low water levels on stones and rock outcrops were to some extent interconnected with other important points. They were linked to zero points of water gauges, initially set up for navigation purposes, and to flood marks. The particular situation in Děčín is therefore a unique example of the epigraphic indication of low and high water levels in the enclosing profile of the upper part of the Elbe River basin. To verify the low water level marks or drought marks, we used the then current scientific studies focussing on dry periods. However, we also used the oldest series of daily water levels
\end{abstract}

measured in Magdeburg, Dresden and Prague, available from 1851 , i.e. the beginning of measurements in Děčín. These series had to be reconstructed or digitised from Czech Hydrometeorological Institute (CHMI) archive sources. Since 1851 we have been able to accurately identify the heights and sometimes even the specific days when the minima were marked.

After a thorough field examination and newly measured data, coupled with data obtained from a review of older literature presenting the first surveys of marks on hunger stones as presented in 1842, older marks of low water levels can be considered a reliable indication of the annual water level minima. The aim of the mark creators was not to make commemorative inscriptions of drought but to register the exact minimum water level. Deviations between the marks and the water gauge records did not exceed $4 \mathrm{~cm}$, and only exceptionally was the disparity greater.

From the material obtained so far, an overall slightly decreasing trend of water level minima since the end of the 18th century is noticeable. The view on minima of the 16th and 17 th centuries is based on only a few items of data, and it is difficult to generalise. However, the minima obtained are comparable to or lower than the data from the critical dry periods of 1842 and 1858 to 1874 . Our verification of low water level marks should be an incentive to process all available epigraphic documents of this kind in the near future in closer cooperation with colleagues from Saxony. The potential of these objects offers a deeper knowledge of periods of hydrological drought and possibly of morphological changes in the Elbe riverbed. 


\section{Introduction}

In recent years, the phenomenon of drought has become the most prominent manifestation of climate change in central Europe. However, objective evaluation and assessment of its extremities is challenging due to difficulties in describing the phenomenon of drought and the varying impacts of it. Drought, along with floods, ranks among the most commonly evaluated hydrological extremes. While a flood is caused by short-term excess of water that causes damage, hydrological drought follows a long-term deepening of water scarcity.

Our contribution is focused on hydrological drought and more precisely on the minima of low levels. Low water levels and flow rates after long periods of precipitation deficit represent particularly valuable information about catchment hydrology.

Therefore, the baseflow, the groundwater accumulation, long-term depletion and hydrological drought propagation are also reported (van Loon, 2015). The minimum water level or flow is, to a large extent, summary information on the status of a given river basin.

Like floods, hydrological drought is difficult to study without an examination of historical events. However, what options do we have regarding low water levels? The available hydrological series usually cover no more than 150 years. The longest hydrological series of measurements in Cairo, 622-1933 CE, representing 1311 years of Nile observations (Shahin, 1985), was used to assess drought and its interrelations with phenomena such as El Niño. In Europe, the longest continuous series comprising measurements of water levels in Magdeburg, Germany, started in 1727 (see the following text), and the measurements in Paris started in 1731 (Delametherie, 1800). However, it is impossible to conceal another complication, namely that systematic hydrometric measurements have, for the most part, only been available since the end of the 19th century. Stable profiles where we can assume the validity of the rating curve as far back as possible are very valuable. Systematic series of water stages are, therefore, testimony to runoff fluctuations but partly also to changes in the stream cross section and the catchment, both natural and anthropogenic.

Studies that focus on the identification of past dry periods and possibly on the wider context within the North Atlantic Oscillation (NAO), El Niño-Southern Oscillations (ENSOs) are based mostly on an analysis of precipitation deficit or indicators that include temperature and hence loss by evaporation (e.g. Mikšovský et al., 2019). They are necessarily based on previous reconstructions of temperatures and precipitation based on an analysis of documentary sources. However, if we want to describe how the rainfall deficits and other weather influences were reflected in the runoff from the surveyed river basin, the options we have so far are rather limited.

Based on the available series of daily flow rates in Děčín, Czech Republic (1851-2015), Brázdil et al. (2015) referred to a period of low flows between 1858 and 1875 .
With the help of deficit volume analysis with a fixed annual $\left(Q_{95}\right)$ and variable monthly $\left(Q_{95} \mathrm{~m}\right)$ threshold, Brázdil et al. (2015) identified the drought events of 1868 and 1874 as comparable to the 1904, 1911 and 1947 dry periods.

The authors elaborated on in detail the selected dry years of $1808,1809,1811,1826,1834,1842,1863,1868,1904$, 1911, 1921, 1934, 1947, 1953, 1959 and 2003, i.e. eight cases in each century representing a total of 16 cases selected on the basis of the lowest $z$-index and SPI1 values out of 10 homogenised precipitation series (Brázdil et al., 2012). The evaluation of particular years includes the meteorological and synoptic conditions, drought impacts, monthly values of air temperature, precipitation, SPI1, SPEI1 and $z$ index. In the identification of hydrological drought in the 1860 s and 1870s, a similar result was reached by Elleder et al. (2020) when analysing the catastrophically dry year of 1874 by analysing the newly reconstructed series of water levels in Prague (1825-1890).

What credible documents of low water levels existed before 1851 (the start of record-keeping in Děčín), 1825 (the start of record-keeping in Prague) or 1727 (the start of record-keeping in Magdeburg)?

Based on reconstructed data on temperatures and precipitation between 1766 and 2015, Hanel et al. (2018) indicated extreme deficits in precipitation, runoff and the water content of the soil surface layer, identifying the droughts of 18581859, 1921-1922 and 1953-1954 as extreme.

However, there is no doubt, similar to flood analysis, that verifying the model results according to the actual water level and flow rate increases their credibility considerably. We have a relatively large range of palaeostage indicators to describe the maximum water levels during a flood. These palaeoflood indicators comprise various types of sedimentary (e.g. slack water flood deposits) and botanical evidence such as impact marks and damage on trees (Benito et al., 2004, 2015; Wilhelm et al., 2019; Schulte et al., 2019).

Low water levels and flow rates for pre-instrumental hydrology are seldom addressed but with some exceptions. For instance, Shamir et al. (2013) presented methodology to identify field-based geomorphologic marks of low flows in ephemeral arid streams that can be indicative of minor flash floods. Unfortunately, the motivation is different, and the potential for indicating historical low flows in humid climates has low utilisation.

Therefore, low water level indicators available through documentary sources are unique data records (Brázdil et al., 2018) for recording past hydrological droughts, with the precision given by physical imprints provided by epigraphic marks.

During drought, attention was paid to objects normally hidden below the water level. Most often these were large boulders, protruding rocks and sometimes even point bars or slip-off slope sandy deposits with specific local names. In many cases these were also artificial objects: protruding foundations of old bridges and building elements. Around the 
Rhine these were the remains of old buildings, old bridges etc. (Wittmann, 1859). Sometimes there was an interesting local tradition; in the sandstone area on the Czech/Saxon border, it was the creation of commemorative inscriptions, particularly inscribing the current year with the low water level. Today, these objects are mostly called hunger stones (hereinafter HSs).

This article focuses on these hunger stones; it seeks to clarify their purpose, origin and meaning. Traditionally, water management experts and historians and perhaps ethnographers in Bohemia considered inscriptions and the year as indicated on hunger stones to be an interesting phenomenon symbolising drought.

At the same time, however, the understanding prevailed that the marks of dry years were merely commemorative records with no deeper meaning and that they were more or less randomly positioned. We believe that it is in this area that we have taken a substantial step forward in the explanation and possible use of these records.

We have therefore focussed on the city of Děćín, located in the lower section of the Czech part of the Elbe River basin. The best-known hunger stone is located here, and all the important height surveying of all the epigraphic marks was undertaken in the summer of 2015. In 2018 the whole stone was scanned. This article discusses to what extent the inscription years have the character of historical minimum water levels. The objective is to document and explain the phenomenon of hunger stones in more detail. We aim to answer the following questions:

1. Are the year marks only commemorative for that dry year and when do they represent exact records of annual minimum water levels?

2. Are there consistent relations in the heights of stage minima among different stones?

3. What is the relation to the systematic series of measurements?

4. Do the elevations suggest any trend in water levels?

\section{The Elbe River region in the Czech Republic and the city of Děčín}

The Elbe River valley between Litoměrice and Pirna was made famous in a number of prints and paintings by 19th century Romantic painters such as Adrian Zingg (17341816) and Caspar David Friedrich (1774-1840). Zingg was Swiss but lived in Dresden; he probably coined the name of the Saxon Switzerland region, which later extended to Czech-Saxon Switzerland (Frölich-Schauseil, 2018). The Elbe, which leaves the territory of the Czech Republic in a deep rocky canyon and ends its upper stretch here, flows between Lovosice and Děčín through the Krušné Ore Mountain system. Along its path it first intersects the volcanic zone of the České středohoří area. Below Děčín, it then flows through a landscape of sandstone formations. The Elbe riverbed is situated at an altitude of about $120 \mathrm{~m}$ above sea level in a deep sandstone valley $200-300 \mathrm{~m}$ below the level of the sandstone plateau (350-450 m a.s.l.). Protruding volcanic formations reach a height of 500-800 m a.s.l. The Děčín and Hřensko cross sections represent the closing profiles of the Czech part of the Elbe. In addition to wood, local sandstone was a traditional building and sculpting material here and throughout the North Bohemia region. However, it was also used for rich epigraphic production on the spot - on rocks and boulders (Jenč et al., 2008). It is quite logical that water levels were recorded adjacent to the river where possible, both minima and maxima.

At the centre of our study is the city of Děčín (Fig. 1), known among other things for its unique series of flood marks (Brázdil et al., 2005; Elleder, 2016a) and hunger stones. The earlier documentation, which comes from commission inspections of the Elbe riverbed, revealed previously unknown facts. In 1842, there were still a total of three hunger stones in the city of Děčín with engraved years: two on the left bank (HS1, HS3) and one on the right bank upstream of the ferry crossing (HS2) (Protokoll, 1842). The preserved stone (HS3), which is located in the lower part of the deeper riverbed, is the centre of our attention.

This place was probably advantageous long ago as a settlement with a ford at the river confluence and below the protruding sandstone ridge. At the end of the 13th century a royal town was founded here (Fig. 1; Velímský, 1991). Possibly in connection with a rich flood period between 1342 and 1374 (Elleder, 2015), it was abandoned and transferred to the other side of the rock ridge, where a castle stood and the manor house is situated nowadays. There were at least two places in Děčín that were problematic from a navigational point of view. The first hunger stone (HS1) was located near the first shallow water area. It is related to the confluence of the Elbe River with the Ploučnice River entering from the right, the Jílovský potok stream from the left and the sediment deposits. On the rock below the castle there are flood marks from 1432 carved into the rock block. Alongside, a water gauge (RG2) is located indicating the Prague ell units of length $(1 \mathrm{ell}=59 \mathrm{~cm})$. This gauge starts at 9 ells above the water level for full navigability (Bohemia daily, 1845). This depth was traditionally referred to as the Fünfspanner, i.e. 5 span, a sufficient navigational depth of 5 spans or $50^{\prime \prime}$ $(125-130 \mathrm{~cm}$ ) for the full loading of the Elbe ships (Bohemia daily, no. 45, dated 4 April 1845). There was a rock block near the shore with a water gauge for low water levels in feet (RG1) (1 to 5 feet), probably related to safe passage. In 1851, water levels in Děčín began to be systematically monitored, initially at the old water gauge (OG) at the site of the navigation directorate. Apparently, the water gauge served for navigation to make ship loading efficient for the second shallow water area. It still bears the original German and now popu- 


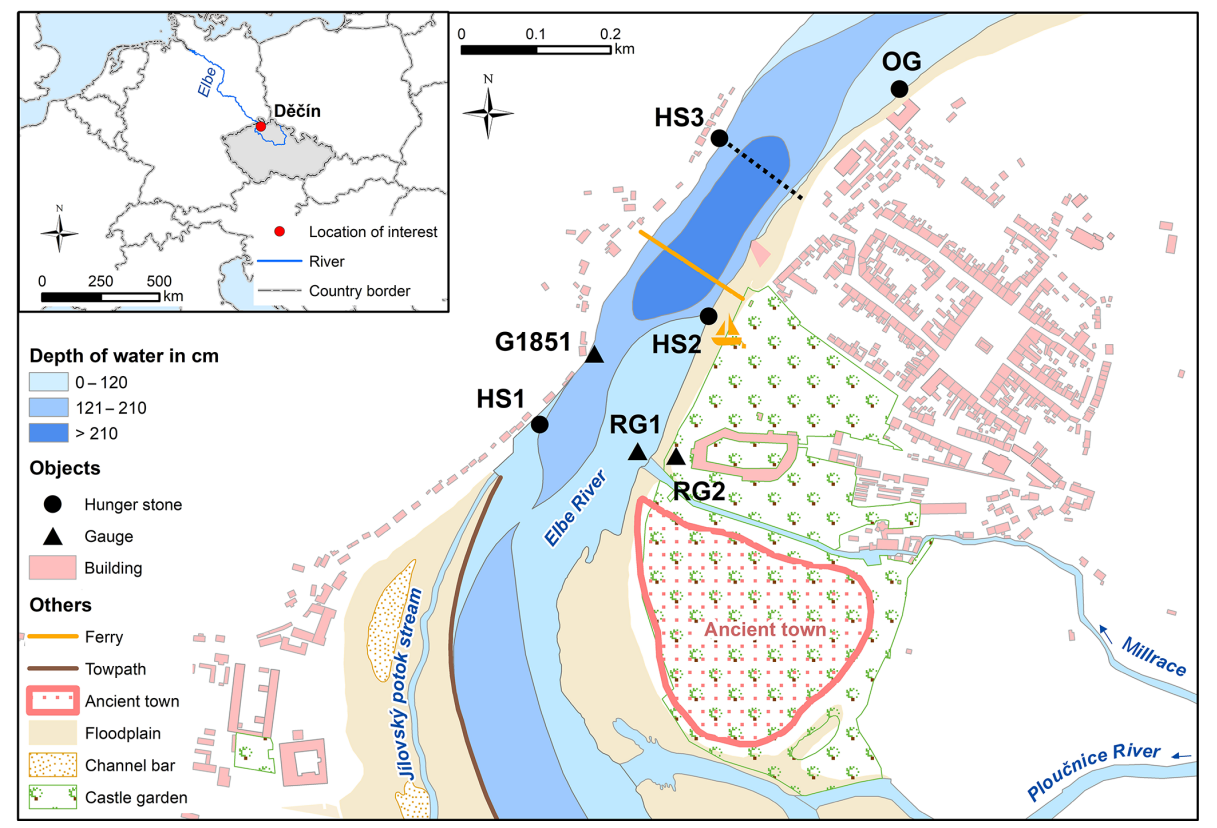

Figure 1. The city of Děčín in 1842 with indications of the original extinct town (13th-14th century), area of shallows (lightest blue), water gauges RG1, RG2, G1851 and OG, and three hunger stones (HS1, HS2, HS3).

lar name of Heger (supervision). Later, the observation was transferred to a new water gauge (G1851) (see Sect. 3.5.).

\section{Methodology}

\subsection{Data and documentary sources}

The first partial goal was to prove that the water level marks on the hunger stone in Děčín and other stones were meant by their creators as signs of annual minima in the years attached to the water level marks. The simplest means are a comparison with concurrent water level measurements on a nearby water gauge (accurate identification) and the use of other available measurements (approximate confirmation of significant water level decline). We used primarily four series stored at the CHMI (Czech Hydrometeorological Institute). These are the systematic series at the sites of Magdeburg (1727-1880), Dresden (1801-1829), Prague (1825-1890) and Děčín (1851-2019).

\subsection{A series of daily water levels in Magdeburg, $1727-1880$}

Prof. Harlacher, the first head of the Czech Hydrological Service in Prague (Elleder, 2012), needed a long water level series for studying past drought periods. In 1875-1880 he obtained the oldest series from the Water Management Directorate in Magdeburg. This record was found 110 years later in the 1990s in the unclassified records of the Czech Hydrological Service. A copy was sent to the International Commission for the Protection of the Elbe River (IKSE) Magdeburg headquarters. Digitisation was carried out in 2005-2007 in cooperation with the CHMI and the T. G. Masaryk Water Research Institute (T.G.M WRI). The value of these measurements is considerable as the series covers the whole period of 64 years in the 18th century continuously, and there is no other alternative for central Europe. Its disadvantage is the downward trend in annual minima, which can be explained largely by the shortening, deepening and changing the profile of the Elbe River around 1816 (Simon, 2010). However, in our case we can identify very well particular annual water level minima and their associations with the years on hunger stones between 1746 and 1800 (hereinafter DM for drought marks or for minimum water level signs). By identifying the annual minimum water level in Magdeburg, we could estimate the likely date of creation of the DM in Děcín, considering the Děčín-Magdeburg water transit time (6d).

\subsection{A series of daily water levels in Dresden, 1801-1829}

A copy of this series, probably made by an official of Prague City Hall in 1829, offers evidence that the systematic series does not begin in 1806 (Fügner and Schirpke, 1984; Fügner, 1990) but at least in 1801. The series was found in the 1990s by a private researcher, Jiři Svoboda, in the Prague City Archives, and he left it to the CHMI. Dresden has a clear advantage over Magdeburg in its geographical proximity to Děčín, so we preferred it for the 1801-1829 period. 


\subsection{A series of daily water levels in Prague, 1825-1890}

In Prague, an occasional water gauge (possibly flood gauge) was probably established by Antonín Strnad, the director of the Clementinum observatory, in the profile of the Monastery of the Knights of the Cross in 1782 (Brázdil et al., 2005; Elleder, 2016a). Later (about 1821) it was transferred to the profile of the Old Town Mills, Prague. Systematic observation of the water gauge started in 1825 (for more detail, see Elleder, 2016a). The profile of the Old Town Mills was related to the weir normal (i.e. to the weir crest), so it was a profile that did not change. According to Novotný (1963), the original observation diaries and perhaps even annual reports of the measurements were lost. Only the published values of the monthly minima, maxima and averages in the yearbooks of the Clementinum observatory remained. As with other observations (e.g. in Magdeburg and Vienna), the Prague observations were published weekly and later daily, in daily newspapers. Therefore, we decided to regain the daily measurements of water levels published in the daily Prager Zeitung, starting with January 1825 . The data were collected for 3 years by an external CHMI associate, Zvonimír Dragoun, in the archive of journals and newspapers of the National Museum in Prague. The measurements were used similarly to the previous series, particularly for the $1825-1850$ period. A special publication will be devoted to the complete time series.

\subsection{A series of daily water levels in Děčín, 1851-2019}

As with other profiles along the Czech section of the Elbe River, a systematic observation of water levels was introduced in Děčín. At first there was an old water gauge (OG) (Fig. 1), which was located in the profile of the site of the steamship navigation directorate probably before 1842 . Later, but probably no earlier than 1858 , the new water gauge (G1851) started to be used on the pillar of the Empress Elizabeth Bridge (built in 1851). The problem is a newfound uncertainty in the change of the zero point of the water gauge (Protokoll, 1858), the height of which might have been elevated by $16^{\prime \prime}$ (i.e. about $42 \mathrm{~cm}$ ) in 1858. It is not entirely clear from when exactly the data from the old annual reports of measurements of the Děčín series are related to the new zero height (monthly reports are available only after 1875). The minima of water levels on hunger stones are therefore partly a possible verification of early measurements in Děčín. Even later, around 1877, the water gauge was transferred to the waterfront (Harlacher, 1883). At that time, from November 1876 to March 1881, Andreas Rudolf Harlacher was performing hydrometric measurements with his colleague, Jindřich Richter, and their associates (Harlacher, 1883). From this time, we have measurements up to $169 \mathrm{~cm}$ of water level at a measured flow rate of $90 \mathrm{~m}^{3} \mathrm{~s}^{-1}$ (Table 1). For interpolation and extrapolation of the curve, the formula $Q=78.09\left(H_{0}+1.45\right)^{1.953}$ was applied. Accord-
Table 1. The oldest measurements of very low flow rates in Děčín and on the Saxon side.

\begin{tabular}{llrl}
\hline & Date & $\begin{array}{r}H \\
(\mathrm{~cm})\end{array}$ & $\begin{array}{l}Q\left(\mathrm{~m}^{3} \mathrm{~s}^{-1}\right) / \\
\text { location of the flow } \\
\text { rate measurement }\end{array}$ \\
\hline Děčín & 28.7 .1876 & 163 & 90/Děčín \\
& 13.10 .1877 & 167 & 96/Děći \\
& 29.8 .1893 & 144 & 63/Děčín \\
& 13.8 .1904 & 119 & 46/Děčín \\
& 29.8 .1911 & 118 & 56/Děćin \\
\hline Dresden & 17.7 .1893 & -179 & 56/Großschepa \\
& 14.7 .1893 & -172 & 63/Kötschenbroda \\
\hline
\end{tabular}

a Old hydrometry (1877-1940). ${ }^{b}$ Elbeströmbauvervaltung (1898).

ing to this formula, the water level at $140 \mathrm{~cm}\left(H_{0}=-60 \mathrm{~cm}\right)$ would correspond to a flow rate of $57 \mathrm{~m}^{3} \mathrm{~s}^{-1}$ ( $H_{0}$ is the water level corresponding to the height of the water before the shift of the zero point of the water gauge by $-200 \mathrm{~cm}$ made on 1 October 1939). Novotný (1963) reports the successive shift of the rating curve and presents the evaluation of historical flow minima. Of these, for the water level of $133 \mathrm{~cm}$ (on 23 August 1868) he reports a flow rate of $50 \mathrm{~m}^{3} \mathrm{~s}^{-1}$ and for the stage of $137 \mathrm{~cm}$ (on 6 September 1874) the value of $54 \mathrm{~m}^{3} \mathrm{~s}^{-1}$. After the riverbed modification around 1896, the curve changed substantially in the section of low flow rates (Table 1). He evaluated the significantly lower flow rate for the water stage at $113 \mathrm{~cm}$ only later, on 19 August 1904, at $39 \mathrm{~m}^{3} \mathrm{~s}^{-1}$. This is a significant difference that would affect the flow rates at the extreme minima of 1868 and 1904, and the question is whether to trust the 1876-1881 curve when it was impossible to evaluate the lowest water levels as the flow rate was significantly higher than average. Hydrometry of low flow rates on the Saxon side has been available since 1886 but for extremes only since 1893 . Therefore, in the results, the flow rates at individual minima are accepted so far with caution.

\subsection{Preliminary verification}

This study was preceded by about 10 years of waiting (since 2005) for a suitable opportunity to undertake a field survey of hunger stones that are totally or partially below the surface at normal summer flow rates. There was no other possibility than to try to find an alternative solution. In 2009, as part of a preliminary study, we tried to use rich iconographic material from the period of 1894-1994 and reports of the hunger stone in Děčín in contemporary newspapers. In the older press materials, reports were looked up that showed when the hunger stone was visible and an indication was given as well as to which year marks were above the relevant water level. Then it was easy to classify the marks into height groups with a water level higher than that of the day reported. 
Further specification of heights was possible only on the basis of photographs by comparing which mark was higher or lower in the given group. The marks were connected by contour lines indicating the resulting bands. The estimated water levels were then compared with the annual minimum values. The result pointed to the expected possible concordance with the annual water level minima. We have followed a somewhat similar approach with the hunger stone in Pirna.

\subsection{Field measurements}

In 2011, it was possible to carry out field verification of the estimated heights of the marks that were located on the highest part of the stone. In 2014, this opportunity was not used as we believed that the dry season would have a longerterm character, which was confirmed in 2015 and 2018. In 2015, the hunger stone in Děćín (HS3) and the stone in Těchlovice were surveyed. During the surveying of the stone in Těchlovice, located on the slip-off slope of gravel deposits, it was not necessary to make any ground adjustments. However, only relative heights recalculated to the minimum height of 1842 were measured.

The surveying of the Děčín stone in 2015 required preparation, including sediment removal and stone cleaning (manual work of two to three people for $3 \mathrm{~h}$ or more). In 2015, the sediment layer reached the mark of 1616 , i.e. around $70 \mathrm{~cm}$ in height. In addition, it was necessary to make a pit around the stone's very low marks. Using a pump with a syringe to wash away sediment, blasting stone and pumping water from the sump significantly accelerated the work.

The measured mark heights were linked to the fixed geodetic point nearby. All surveyed geodetic levelling points were photographed. The measurement took place on 14 August when water levels dropped to their lowest just before the expected rainfall episode which increased the Elbe water level significantly. The participants in the measurements were Ladislav Kašpárek and Jan Kašpárek from T.G.M. WRI, Libor Elleder from the CHMI, and a land surveyor, Zvonimír Dragoun (presented at EGU 2016; Elleder, 2016b).

We did essentially the same when scanning and creating a 3D model in 2018. The stone was prepared by colleagues from the CHMI (Martin Groušl, František Pěkný and Martin Hubený) in advance on 27 July. The final adjustment was made on the day of the measurement and was assisted by Daniel Kurka, Libor Elleder and Martin Hubený. Martin Hubený also performed a hydrometric measurement in the hunger stone profile (HS3; Fig. 1), including the cross-section measurement using the ADCP (acoustic Doppler current profiler). Three-dimensional scanning was performed by Libor Tělupil from the VR3D Company (http://vr3d.cz, last access: 1 July 2020) on 30 July, which lasted for about 3 to $4 \mathrm{~h}$. Similarly, the marks on the rock in the (RG2) profile were scanned. Because scanning requires soft, shadow-free lighting, a temporary stand was placed over the stone. The whole event was docu- mented by the local press (https://www.idnes.cz/usti/zpravy/ decin-vodomer-hladovy-kamen-skenovani-3d-model.

A180730_113803_usti-zpravy_mi, last access: 1 July 2020), and the result is partially accessible on the CHMI website (http://portal.chmi.cz/historicka-data/hydrologie/ zaznamy-z-minulosti/hladovy-kamen, last access: 20 June 2020). Both measurements in 2015 and 2018 were performed during hot summer days with temperatures of $38^{\circ} \mathrm{C}$ in the first case and around $30^{\circ} \mathrm{C}$ in the second case. An independent surveying campaign was carried out in 2015 by the Elbe River Administration, a state enterprise (Randák et al., 2015, 2017a, b), and in 2018 also by hydrologists and archaeologists from Saxony (Walther et al., 2018).

\subsection{Measurement processing}

In 2015, 33 points were surveyed, mostly engraved lines with attached year indications. For obvious reasons, making a DM is much more difficult than making a flood mark. It is difficult to estimate when the water level starts to rise (see discussion). Therefore, it was not always certain whether the sign would represent an indication of the immediate low water stage (LL), the local minimum (LM) or the annual minimum (AM). For verification and approximate determination of the minima marked on hunger stones prior to 1727 , only documentary sources are available: i.e. reports on weather and impacts of hydrological drought, such as the drying of smaller streams and wells, the shutdown of small and medium mills, or the necessity to travel dozens of kilometres to a grain mill. We reproduce this information primarily from Brázdil et al. (2015). The decade frequencies of drought occurrence since 1500 (Brázdil et al., 2013) were a valuable basis for verifying the position of marks, especially for the 16th and 17 th centuries.

For the evaluation of the DMs made after 1727, we used the above-mentioned series of measurements in the Magdeburg series rather for dating verification and the Prague and Dresden series for assuming a very approximate estimate of the significance of the minimum. Concerning newer cases after 1851, it is possible to confirm the correct or incorrect position of the mark (DM). Regarding deviations from the measured water level for that day, we consider the precisely marked height (PMH) at a deviation of $0-4 \mathrm{~cm}$ and approximately marked height $(\mathrm{AMH})$ at a deviation of $4-8 \mathrm{~cm}$. We consider larger deviations as a possible mistake when placing the measuring rod or a poor understanding of a difficult-toread position of the mark or line. If the DM does not have accurate dating, we can assume dating according to the minimum water level when there is an exact PMH identification with the minimum water level.

One very important product is the digital model of a hunger stone, which can be viewed and edited in contrasts by selecting the "Shaders" option in the MeshLab processing system (http://www.meshlab.net/, last access: 1 July 2020), thus clarifying unclear situations and illegible marks. Given 
that at the time of measurement we had not always understood the situation in situ, it was possible to derive the missing height from the digital model by reading the position $(x, y, z)$. Thus, the second mark was found on DM1616, DM1536 etc. In the survey diary, the actual measurement is clearly arranged and documented by photographs of the position of the measuring rod and by highlighted views of the described parts of the stone. The measured heights of all marks and their positions are presented on the stone, which is divided into four height zones and the embankment side (ES), left side (LS), right side (RS), front platform (P) and the highest parts of the ridge $(\mathrm{R})$. The presentation of the marks is chronological so that the information is combined into a logical complex.

\subsection{Complementing measurements according to other objects}

Some DMs are missing on the Děčín stone, but we find them elsewhere. If their heights were measured during commission inspections of the Elbe River in 1842 (Protokoll, 1842) and 1850 (Protokoll, 1850), relative to the level of 1842, these differences can be utilised. Thus, some heights $(1766,1782)$ from the lost stone in Děčín (HS1), Dolní Žleb (1516, 1615, 1636, 1706, 1834 and 1835) and Pirna (1706, 1834 and 1835) were added. For other hunger stones, we can only take into account the positions of the marks, reviewing whether they are in accordance with or contrary to the facts found.

\section{Results}

\subsection{Brief history of low water stage records in context}

\subsubsection{The oldest documented field surveys of Czech rivers from 1640 to 1727 and trends in water levels}

It is very likely that the most objective records of hydrological drought or, more specifically, records of low water levels are related to navigation in central Europe (Brázdil et al., 2019b, mentioned a limiting of water transport in the years 1686 and 1746). It cannot be ruled out, for example, that the mapping of the Vltava River (by David Altmann of Eidenburg) and the river regulation by Kryšpín Fuk (1640-1643), abbot of the Premonstratensian monastery in Strahov (Wiesenfeld, 1844), were made possible merely by a drier period, probably culminating in 1642 (documented by Pekař, 1998). Also, surveys of the upper Vltava River reaches, carried out by Lothar Vogelmonte for the intended canal between the Danube and the Vltava rivers in the years 1700-1715, show a possible time relationship (Wiesenfeld, 1844). The dry years of 1705, 1706 and 1707 (marked on hunger stones) could present an opportunity to explore the streams in times of low water levels. The drought in 17261728 clearly affected the beginning of water level measurement in Magdeburg (Hofmann, 1850) in 1727. It was probably connected with the frequently quoted commission of Jan
Ferdinand Schor, which carried out a survey of the Vltava River with regard to navigation and the construction of the first lock chambers (Wiesenfeld, 1844). The agreement on duty-free navigation on the Elbe (see Faulhaber, 2000, 2013) in 1821 (the year was also marked on the stone in Děčín, HS3) along the Elbe River up to Hamburg led to increased interest in monitoring water levels for individual participating states, including the Austrian Empire and Saxony up to Denmark.

The catastrophic dry period of 1834-1836, affecting both the Elbe and the Rhine basins, raised the issue of a general downward trend in water levels, especially in the Elbe basin. $\mathrm{H}$. Berghaus pointed out this trend and the poor prospects of Elbe navigation (Berghaus, 1836, 1854). A forestry expert, Reuter of Aschaffenburg (Reuter, 1840), pointed out the possibility of this trend being linked to the deforestation of the central European landscape.

\subsubsection{The Elbe Commission in 1842}

In this context, there is a link with the disastrously dry year of 1842 (Brázdil et al., 2019a, indicated that in 1842 summer precipitation was significantly reduced from western to central Europe), and a commission of the Elbe states (Austria, Saxony, Prussia, Anhalt, Hamburg and Denmark) was organised to improve navigation conditions. The aim was a thorough description of all fixed points (water stage gauges, flood marks and marks on hunger stones), navigation conditions and minimum navigation depths along the navigable section of the Elbe from the town of Mělník (Bohemia) to Cuxhaven (Saxony). Stones and rocks in the river were of dual importance for navigation. They were a dangerous element, but at the same time they served as orientation for navigation. The commissioners travelled by boat, and the Mělník-Meissen section was surveyed from 5 to 11 September $1842,14 \mathrm{~d}$ after reaching an absolute minimum water level. The water levels of the Vltava and Elbe were still very low, but they were already 9 to $20 \mathrm{~cm}$ higher than the minimum of the previous August. In the city of Děčín, measurements were made from 7 to 8 September (Protokoll, 1842) at a water level of about $3.5^{\prime \prime}(9 \mathrm{~cm})$ above the 1842 minimum. Three hunger stones in Děčín (Fig. 1) and one in Dolní Žleb were identified and surveyed. On the Czech side, a water gauge in Litoměřice and a water gauge for navigation purposes in Děčín were noted in the section between Mělník and the state border (in both cases there were no regular records available). On the Saxon side, water gauges managed by the Royal Saxon Directorate for Water Construction (Königl. sächs. Wasserbaudirektion in Bad Schandau, Pirna, Dresden, Meissen and Riese were identified. The hunger stones were detected and partially surveyed in the following locations: Schmilka and Pirna (see the text below) (Protokoll, 1842). 


\subsubsection{The Elbe Commission in 1850}

The commission compared the situation with the last commission survey in 1842 and registered the removal of some barriers to navigation. Gauging some low water levels through their relation to fixed points is of the utmost importance to the subject of this study. These fixed points were only flood marks (in Roudnice, Ústí nad Labem, Děčín), and alternatively the current water levels in 1850 , or zero point of a water gauge, were used (old water gauge in Litoměřice, Ústí nad Labem, railway water gauge in Dolní Žleb, water gauge in Pirna). Until now, only two of the original three hunger stones remained in Děčín. The Austrian commissioner carried out a precise survey of all the flood marks on the castle rock in Děčín (Krolmus, 1845; Brázdil et al., 2005) and related their heights to the minimum of 1842. The commission was active in September when there was a significantly higher water level than in 1842 . Therefore, the marks on the hunger stones were underwater and thus were difficult to recognise. For the present stone (HS3), its top at $14^{\prime} 1 / 2^{\prime \prime}$ $(37.7 \mathrm{~cm})$ was below the then current water level. Since, according to our measurement, the top is at the water level $H=176 \mathrm{~cm}$, the then current water level was about $214 \mathrm{~cm}$ and the flow rate was about $190 \mathrm{~m}^{3} \mathrm{~s}^{-1}$ (according to Harlacher's rating curve, 1883). The commission had a new map of the Vltava River and the Czech Elbe River, which was created between 1843 and 1848 (Elbekarte, 1848) with depths in cross sections already marked. In the following year, on 1 January 1851, the daily observation of water gauges on the Czech Elbe River in the cities and towns of Mělník, Roudnice, Litoměřice, Ústí nad Labem, Děčín and probably Dolní Žleb began. Zero points of the new gauges were established $6^{\prime \prime}$ above the minima of 1842 (Protokoll, 1858). At this stage, half-cargo navigation was possible (Wex, 1873).

\subsubsection{The commission and the catastrophic drought of 1858}

The year 1857 was very dry, just as 1858 proved to be. The commission was in Děčín on 20 May 1858. The water level was in the range of -0.75 to $-2.5^{\prime \prime}$ (about -2 to $-7 \mathrm{~cm}$ ) according to the new water gauge. Just before that, according to the Protokoll (1858), the height of the zero point of the water gauge in Děčín and Dolní Žleb was increased by $16^{\prime \prime}(42 \mathrm{~cm})$. The commission identified the 1857 minima as generally the lowest in the period between 1842 and 1858 .

Considering the record low water levels of the Rhine, Josef Wittmann, director of the Society for the Study of the History and Monuments of the Rhineland, published a comprehensive publication (Wittmann, 1859), which is also an inventory of periods with low water levels of the Rhine from 70 CE (Tacitus' description of the very low water level of the Rhine) to 1858 and an overview of prominent objects hidden underwater during a normal water stage of the Rhine. According to his work, the level of the Rhine dropped to a record low in 1858, lower than in 1788, 1813, 1818, 1822 and 1830, at least according to the water gauge in Cologne. It was this alarming water level that was simultaneously the main motivation and the opportunity for his work. The year 1858 was recently indicated by Hanel et al. (2018) as one of the most extensive drought periods. The years 1857 and 1858 in the Elbe basin are also the beginning of 2 decades of the occurrence of significant and catastrophic periods of low water levels. These periods are represented by the years 1858, 1863, 1864, 1865, 1868, 1873 and 1874 (Elleder et al., 2020), most of which can be found on various hunger stones in the Elbe. At that time Professor Bruhus of Leipzig (Bruhus, 1865) was studying hydrological drought in Saxony. His work was the basis of a study by the forest counsellor von Berg (von Berg, 1867), which again presents the same idea of the loss of water throughout central Europe and documents it with the help of precipitation balances and minimum water levels not only in the Elbe, Oder and Rhine but also the Elster and Mulda rivers. The author saw the cause again in the intensive use of the landscape, especially deforestation. The prominent Austrian water manager G. von Wex (Wex, 1873) applied the recorded minima of water levels from 1616 to 1842 when demonstrating a steady downward trend in 1842-1873. He also recalled the earlier views of Heinrich Berghaus and the Prussian Counsellor Hagen. However, Hagen refuted the downward trend for the Rhine, for example. On the other hand, Heinrich Grebenau, a noted expert in hydrometry who also participated in the famous international survey of the Rhine in 1867, supported the idea of flow decline with his flow measurements.

This drought also had a specific impact on Bohemia, the most industrial part of the Austrian monarchy. In 1869, another Elbe navigation commission (Wex, 1873) was held. In 1871, Andreas Rudolf Harlacher, a professor at the Prague Technical University, established a temporary station for hydrometric observations and for calculating the amount of runoff from the Czech Elbe (1871-1872) (Harlacher, 1871, 1872). According to Cvrk (1994), the year 1873 brought the intensification of river regulation of the lower Elbe (mostly digging and removing boulders) and finally the deepening of the riverbed by approximately $20-30 \mathrm{~cm}$. The catastrophic drought in 1874 led, after a broad discussion, to the establishment of the Hydrographic Commission of the Kingdom of Bohemia based in Prague (Elleder, 2012). The floods and the generally wetter period of 1880-1882 ended the long occurrence of drought during the period of 1858-1878. Extensive hydrometric measurements, including a detailed mapping of the riverbed, were made by Harlacher in Děčín between the old road bridge and the railway bridge in the 1880 s (Harlacher, 1883). Harlacher was interested, as Berghaus earlier and von Wex at the same time, in the downward trend of the Elbe water levels. Therefore, he collected the abovementioned series of measurements (Dresden series 18061872, not found at the CHMI, and Magdeburg series 17271880). 


\subsubsection{River regulation of the Elbe - earlier and thus more frequent appearance of hunger stones}

After the period from 1880 to 1891 , the low water levels in 1892 and 1894 intensified the pressure to regulate the Elbe. In 1896, a canalisation commission was established for the regulation and canalisation of the Elbe between Mělník and Ústí nad Labem. The aim was to build a navigation link up to Prague and ensure a navigation depth of $180 \mathrm{~cm}$ (an increase of $50 \mathrm{~cm}$ ) in the period of 1896-1938 (Cvrk, 1994). This is a very important fact for our work, as it resulted in a substantial shift of about $50 \mathrm{~cm}$ in the flow rating curve in the Děčín profile in the area of low flow rates.

The next stage was to put into operation the Vltava cascade, the construction of the Slapy waterworks in 1957 (https://www.kct-tabor.cz/gymta/VodniPrehrady/ Slapy/index.htm, last access: 2 July 2020) and the Orlík waterworks in 1963 (https://www.kct-tabor.cz/gymta/ VodniPrehrady/Orlik/index.htm, last access: 2 July 2020). After this date, the minima of flow rates were significantly higher than the previous ones ( 36 to $51 \mathrm{~m}^{3} \mathrm{~s}^{-1}$ ). In times of low water levels, the flow rate is sometimes enhanced by as much as 20 to $30 \mathrm{~m}^{3} \mathrm{~s}^{-1}$. For this reason, the flow minima today are around 65 to $75 \mathrm{~m}^{3} \mathrm{~s}^{-1}$. This means that we need to divide the tags on HS3 into at least three basic groups: (a) 1516-1896, (b) 1897-1956 and (c) 1957-2020.

\subsection{Hunger stones and other indicators of low water stages in the European context}

\subsubsection{Hunger stones, antique monuments and other indications of low water stages in the Rhine basin}

Wittmann's work suggests that the oldest designation dates back to 1305 in Olten on the Aare River and in Strasbourg in the same year or in 1302 or 1303 . The most notable example is the so-called Laufenstein in Laufenberg at the confluence of the Aare and the Rhine, which used to be visible when the flow of the Rhine decreased below $300 \mathrm{~m}^{3} \mathrm{~s}^{-1}$. Civil Engineer Heinrich Walter surveyed the marks on this stone around 1890 (Walter, 1901). There were a total of $10 \mathrm{DMs}$ : 1541, 1692, 1750, 1764, 1797, 1823, 1848, 1858, 1891 and 1893. Walter reported the height above sea level for the marks from 1541, 1750, 1858, 1891 and 1893. Some marks were compared with the observed series and corrected by Pfister et al. (2006). Near Unkel in the dry season of 1766, the dates of 1521, 1567 and 1639 were visible on the basalt rock called Unkelstein (i.e. basalt in the land of Rhineland-Palatinate in translation). However, the situation in autumn 1766 was a quarter foot lower (Johannes Jansen notes, Weikinn, 2000). In the past, there were several places in the Rhine basin known as Hungerstein or Hungerfelsen. One of the oldest pictorial documents was published by Matthäus Merian (Merian, 1645), perhaps according to the field sketches of Prague graphic artist Václav Hollar, who after emigration cooperated with Merian. In the foreground is the Ara Bakchi,
Altarstein or Elfenstein (Figs. 2 and 3), which is just one of the sites that used to be accessible only during the low water stages of the Rhine.

Among similar objects there is, for example, the rock in Olten in the Aare River. Around Bodensee (Lake Constance), such objects indicated low lake levels in Staad, Mammern and Konstanz. In 1750, the remains of the assumed ancient buildings, the pillars of the bridge in Cologne and the aforementioned Altarstein were visible during low water levels, and in 1746 the pillars of the old bridge in Mainz were visible (Fig. 3). The tradition of storing 12 bottles of wine at a hunger stone on the bottom of the Moselle in Trarbach is also remarkable.

\subsubsection{Hunger stones on the Elbe and their removal}

Along its upper reaches the Elbe is a much smaller river than the Rhine, for example, in the narrow canyon area between Bingen and Koblenz (with an average flow rate of approximately $2000 \mathrm{~m}^{3} \mathrm{~s}^{-1}$, minimum around $400 \mathrm{~m}^{3} \mathrm{~s}^{-1}$ ). The Elbe has an average flow rate of approximately $300 \mathrm{~m}^{3} \mathrm{~s}^{-1}$ between Děčín and Pirna. Without the enhancement by the Vltava cascade, the minimum flow rate was dropping until 1957 (the beginning of operation of the Slapy water reservoir) and 1963 (the beginning of operation of the Orlík reservoir), and it dropped as low as approximately $35-41 \mathrm{~m}^{3} \mathrm{~s}^{-1}$ in the years 1904, 1911, 1921, 1934 and 1947 (Novotný, 1963). The lowest water levels were recorded in the Rhine in October and in the winter. Low water levels of the Elbe typically occur from June to September, but in 1874, for example, they lasted until December (Elleder et al., 2020). However, low levels were recorded even in winter during times of severe frost. On the Czech side downstream, the first but rather modern stone was the object in Lovosice (since 1904), then in Těchlovice (1 HS, an additional HS object), Děčín (1-3 HS objects), Dolní Žleb (11 HS objects), Hřensko (15 HS objects), Schmilka (1 HS), Köningstein (2 HS objects), Pirna (2 HS objects), Wehlen (1 HS), Pillnitz (1 HS), Dresden (3 HSs), Meissen (?) and Strehla (1 HS) (see Fig. 3).

The term Hungerstein was not often used in the 19th century. In scientific literature we find the names of the low water levels as Merkzeichen der Wasserstände (Neue Schriften, 1845), and in the news reports the term millstones as Malsteine appeared. The commissions' reports in the Protokoll $(1842,1850)$ mention the stones as Steine and the remarkable ones as Merkwürdige Steine. The Elbe in the sandstone canyon used to be rich in local names: Frog Stones or Froschsteine (Dolní Žleb) (Protokoll, 1842, p. 44), as well as Monk's Stone (Mönchstein) and Millstone (Malstein), which were removed in 1858 (near to the customs office in Dolní Žleb). Two hunger stones with dates (see the text below) opposite the church were designated for blasting. In 1842, stones near Žertovice and, in 1850, on the Saxon side at the Ober Vogelsang site (the Hermsteine) were blasted away. The term Hungerstein appeared in a newspaper article in 


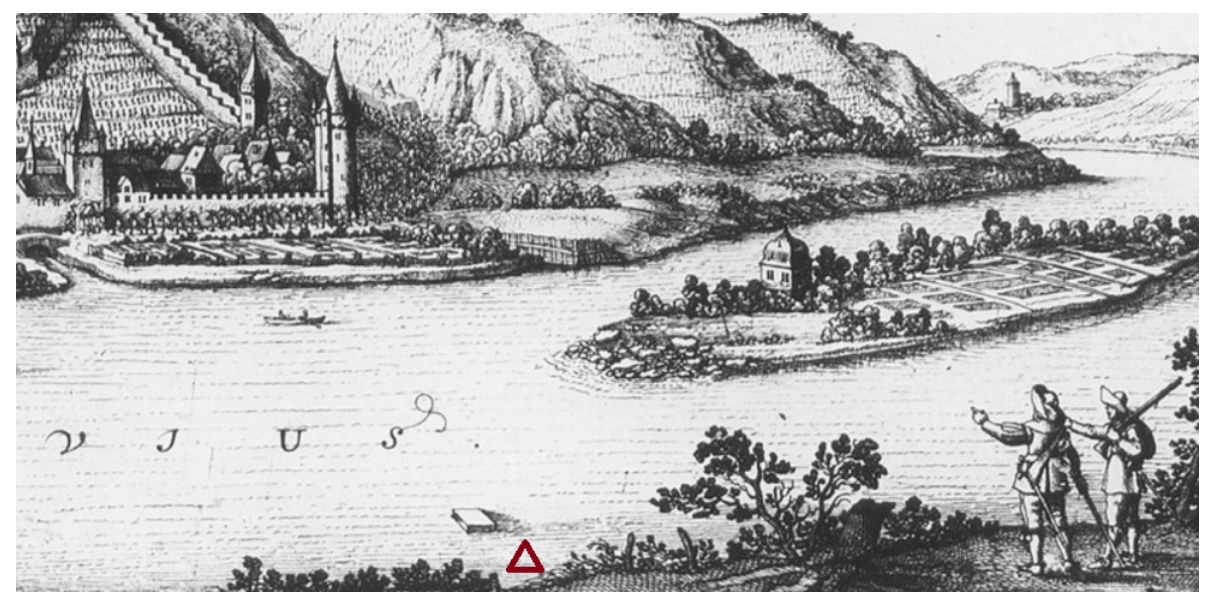

Figure 2. Drawing documenting the position of the hunger stone known as Ara Bakchi, Altarstein and Elfenstein near Bacharach, perhaps in the dry season of 1636, 1639 or 1642 (Merian, 1645), the position of which is marked by a red triangle in a cut-out view of Bacharach.

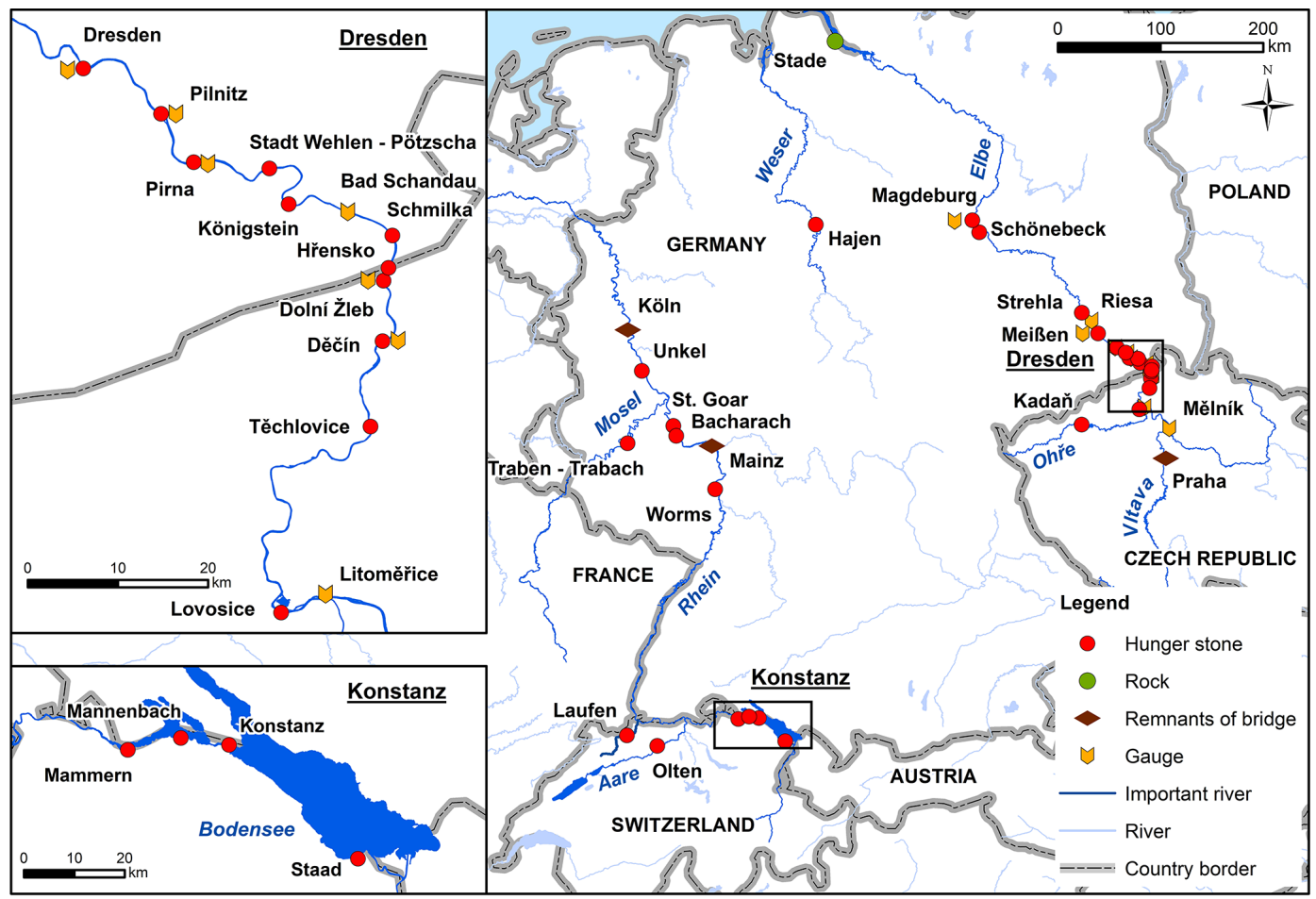

Figure 3. Central Europe and the occurrence of objects similar to the hunger stone in Děčín.

1842 (Pillnitz), in a newspaper in connection with a HS in Meissen in 1865 (Rumburger Zeitung, no. 47, dated 11 October 1865) and in 1876 (Teplitzer Zeitung, no. 98, dated 30 August 1876). The Czech-derived mutation, hladový kámen (hunger stone), was introduced by the regional daily $\mathrm{Jiz}$ eran (17 September 1892) during the drought of 1892.

\subsubsection{Hunger stone in Těchlovice}

The site is located above the sandstone canyon, and the valley is formed by rocks of volcanic origin. On the left bank of the Elbe River, approximately $85 \mathrm{~km}$ downriver (below Mělník), the Elbekarte map (1848) shows the Mändelstein in the riverbed, but the actual stone is on a gravel bench and the affinity of the objects is unlikely. The Protokoll (1842) mentions a strong current and a place with a depth of $1^{\prime} 8^{\prime \prime}$, which is only about $50 \mathrm{~cm}$. The Protokoll (1850) only reports on depths around $160 \mathrm{~cm}$, and another Protokoll (1858) does 
Table 2. Survey of DM heights in Těchlovice.

\begin{tabular}{rrrr}
\hline Year & $H_{\mathrm{R}}$ heights $(\mathrm{cm})$ & $H_{1842}(\mathrm{~cm})$ & $H_{\mathrm{DE}}(\mathrm{cm})$ \\
\hline 1842 & -104 & 0 & 132 \\
1874 & -108 & -4 & 128 \\
1892 & -109 & -5 & 127 \\
1904 & -133 & -29 & 104 \\
1928 & -114 & -10 & 122 \\
1980 & -102 & 2 & 134 \\
2015 & -150 & -46 & 86 \\
\hline
\end{tabular}

$H_{\mathrm{R}}$ - water level of DM, levelling in 2015 linked to auxiliary point; $H_{1842}$ - DM water level relative to the level of DM1842; $H_{\mathrm{DE}}$ - water level accommodation to present Děčín gauge $\left(H_{\mathrm{DE}}=H_{1842}+132 \mathrm{~cm}\right.$.

not mention depths or stones in Těchlovice at all. The estuaries of the two streams create flow sediment cones, and during low water levels the stone is separated from the water and lies on a wide gravel bench. For technical and time reasons, only relative geodetic and height measurements (relative heights $H_{\mathrm{R}}$ ) were made in 2015 . There are seven marks on a flat boulder of volcanic origin $(1868,1874,1892,1904,1928$, 1980 and 2015) (Table 2). The mark of 2015 was prematurely made by an unknown person and does not correspond accurately to the minimum water stage that occurred later.

\subsubsection{Hunger stones in Děčín}

In 1842, three hunger stones were examined within the activities of the Elbe Commission (Protokoll, 1842) (Fig. 1).

According to the report, the first hunger stone (HS1) was located near the left bank of the Elbe opposite the castle rock, i.e. also opposite the well-known flood marks from 1432 to 2013 and the historical rock water gauge (RG2) on the right bank (Brázdil et al., 2005) (Fig. 1). On the stone (HS1), the approximate depths of DM minima in 1719 and 1766 were measured in September 1842. The 1782, 1790, 1835 and 1842 marks were surveyed precisely (Table 1). Elevation ratios were expressed as heights above the previous August minimum of 1842. In 1850, the depth of the 1782 mark (HS1) was determined as $7.5^{\prime \prime}(19.5 \mathrm{~cm})$ below the water level, and the 1842 mark was not visible (it is seen in Table 1 that it was $41.5 \mathrm{~cm}$ below the water level). The Protokoll (1850) implies a link of this mark with a water gauge for low water levels (RG1) on a rock formation with a scale ranging from " $1 \mathrm{~F}$ " to " $5 \mathrm{~F}$ " ( $5 \mathrm{Fu} \beta, 5$ feet). It is a question whether this gauge was linked to a large gauge on the castle rock (RG2). A similar water gauge, which may have been partially preserved, is described by the commissioners at the HS in Pirna.

The second hunger stone (HS2) was supposed to be upstream of the ferry crossing on the right bank. There was a minimum mark from 1800 situated $4.5^{\prime \prime}$ (approximately $11 \mathrm{~cm}$ ) above the minimum of 1842 . In 1850 the commissioners stated that the first (HS1) and the third stone (HS3) remained in place, while the second stone (HS2) was already unavailable at the time of the second commission's work. It is stated that the reason was the construction of the railway (Protokoll, 1850). Since the railway was on the left bank, we tend to consider the possibility that the stone disappeared during terrain works for the construction of a new bridge (opened only later in 1851). The railway was built between 1847 and 1848, and operation started in 1851.

The third stone (HS3) was located by the commission on the left bank, and it still exists. This object is the centre of our focus. The commissioners described the 1616, 1746 and 1790 marks, which were documented many times later in 1892, 1904, 1911 etc., and they also mentioned the 1835 mark (not found). Unfortunately, they only determined a difference of $5^{\prime \prime}(12-13 \mathrm{~cm})$ between the higher minimum of 1616 and the then lowest minimum of 1842 (a difference of $11 \mathrm{~cm}$ was determined in 2015).

The stone (see the methodology) was divided into four height ranges and the following sides: embankment side (ES), left side (LS), right side (RS), platform (P) and the highest part of the stone's ridge (R) (Table 3; Fig. 4)

The platform $\mathrm{P}$, the ridge part $\mathrm{R}$ and the side (ES) of the stone are about $360 \mathrm{~cm}$ wide, and the distance between the bank and the river is about $400 \mathrm{~cm}$. The oldest marks -1536 , $1616,1746,1790,1800,1811,1842$ and 1868 - were placed on the side (ES) facing the river bank in the range of 111 to $150 \mathrm{~cm}$. Only the mark of 1707 was placed on the platform $(\mathrm{P})$, where the markings from 1892 to 1904 continued. The minimum marks of 1904 and 1911 were simultaneously placed on the right side of the stone (RS) (downstream). The lack of space also apparently led to the rewriting of the inscriptions at the 1911 mark and a large inscription: "Wenn $d u$ mich siehst...". The marking of 1921 returned from the side (ES) to the right side (RS), which was not large enough for a new lower marking below $100 \mathrm{~cm}$. Deeper marks in 1930, 1934 and 1947 were placed again on the side of the stone (RS). The demanding 1947 mark is also on the left corner (LS) of the stone. The latest markings of 1957, 1990 and 2003 are again on the lower part of the platform (P) and the mark of 1963 on the ridge (R). The marks of 2015 and 2018 were not placed on the stone. An overview of the water level minima of measured and derived heights is given in Table 4. The list of marks in Table 4 is chronological so that the information is combined into a logical complex (detailed information is included in the Supplement).

Using the example of the measurements in 1850 , it is possible to clarify the system of rock gauges - RG1, RG2 and $\mathrm{OG}$ - linked to hunger stones and the newly measured heights of the flood of 1784 (measured in 2004) and the minimum of 1842 (measured in 2015). An administrator at the Děčín estate, who was also a forester and contributor to the Patriotic Economic Society Seidel (Neue Schriften, 1845), determined the height of the flood mark of 1784 on the rock gauge (RG1) as $32^{\prime} 1^{\prime \prime} 10^{\prime \prime \prime}$ (i.e. $10.16 \mathrm{~m}$ ) above the minimum stage of 1842 (the height today is $131.296 \mathrm{~m}$ a.s.l. of the Baltic vertical system (Bpv) after equilibration). This height 


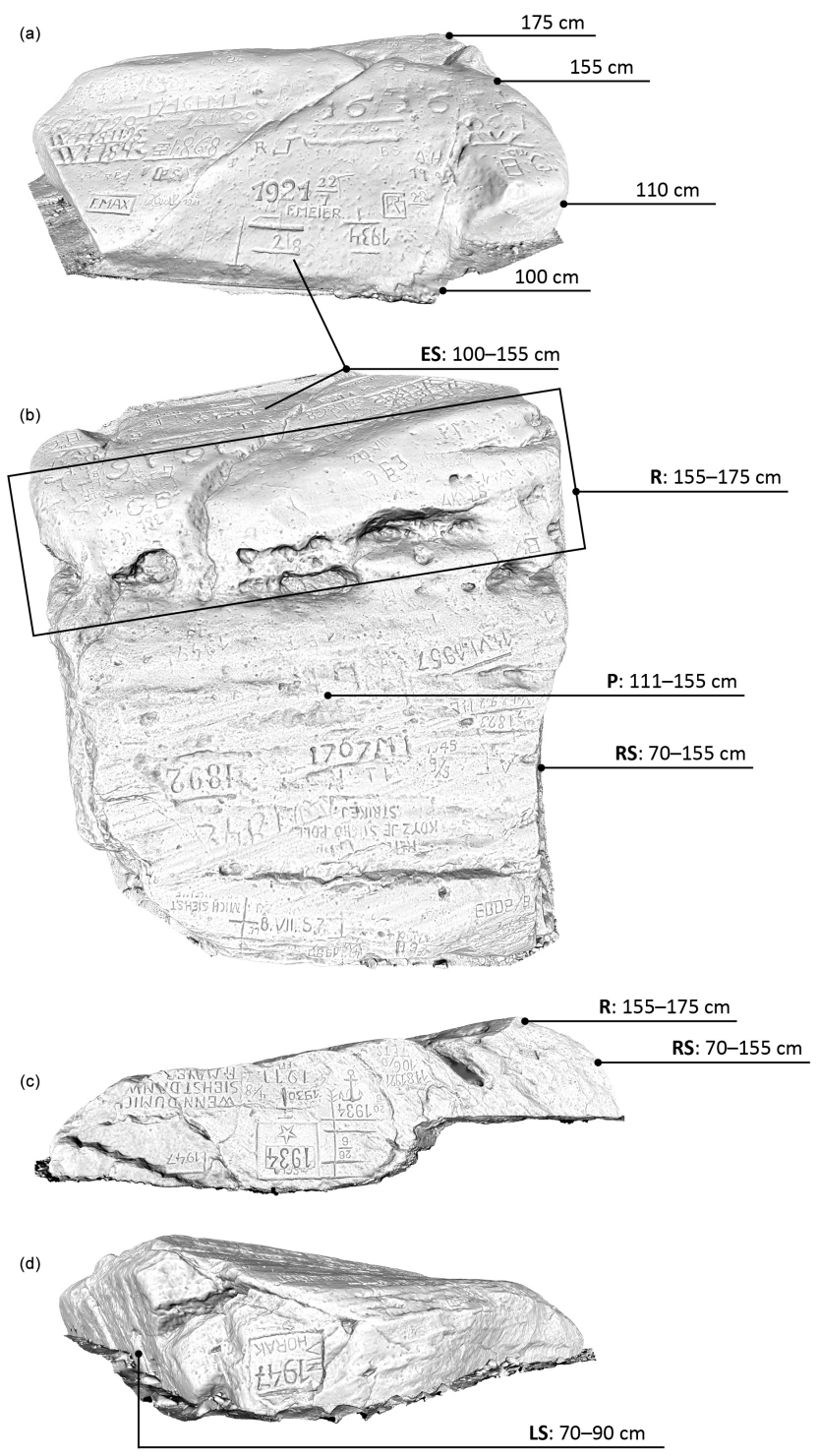

Figure 4. The hunger stone was divided into four height ranges (Table 4) and the following sides (a-d): embankment side (ES), the highest part of the stone's ridge (R), platform (P), right side (RS) and left side (LS).

after deduction (i.e. $121.133 \mathrm{~m}$ a.s.l. Bpv) is $25 \mathrm{~cm}$ lower than the 1842 mark on the stone (HS3).

\subsubsection{Hunger stone in Dolní Žleb (Niedergrund)}

In the river map (Elbekarte, 1848), a total of seven to eight stones are marked on the right bank of the Elbe River upstream of Dolní Žleb, followed by another six downstream, as indicated in the Protokoll (1842). At the former customs house (left bank), the Elbe River flow was narrowed by two rock outcrops: the Monk's Stone (Mönchstein) and the Mill Stone (Malstein), which were removed in 1858 (Protokoll, 1858). Not far from them, in the middle of the stream op- posite the church, two stones were identified in 1842 with the year ending in " 16 " which was 12 " $(30 \mathrm{~cm})$ underwater. Some sources (Neue Schriften, 1845) date the marking back to 1516 or 1517 . The commission measured the depths of the 1616, 1706 and 1842 minima (Table 5), further depth data were designed to be surveyed accurately by geodetic levelling and then the stones would have been blasted off as an obstacle. The regional literature (Focke, 1879; Pažourek, 1995) states that an inscription, "I A B R O 1516 - CB 1615 - VC 1634", should have been on the stone, which means "Ich Andreas Beutel, Richter der Ortes 1516", "Christof Beutel 1615" and "Christof Vogel 1634". According to the latest field surveys (Table 6), a total of 11 hunger stones were found between the positions of 730.55 to $732.01 \mathrm{~km}$, one of them having the year marking of 1842 (Randák, 2015, 2017a). Identification of the described stones is not yet possible.

\subsubsection{Hunger stones in Hřensko}

None of the commissions $(1842,1850$ and 1858) identified a stone with a year indication. The survey carried out by experts of the Elbe River Board on 26 August 2017 (flow rate $75 \mathrm{~m}^{3} \mathrm{~s}^{-1}$ ) determined 14 objects with markings, all of which originated after the commission in 1842 (Table 7).

\subsubsection{Hunger stone in Schmilka}

On the right side upstream of Schmilka, the commission (Protokoll, 1842) found a large stone with an 1842 mark (4 September 1842), which was $4^{\prime \prime}(10 \mathrm{~cm})$ below the then current water level. Further, an 1811 mark was found that was placed $3^{\prime \prime}(7.5 \mathrm{~cm})$ higher.

\subsubsection{Hunger stone in Stadt Wehlen-Pötzscha}

A mark from 1868 remains there today.

\subsubsection{Hunger stones in Königstein}

The commission did not mention any remarkable stones there in 1842,1850 or 1858 . However, German sources mention the year 1681 , and on another stone there are marks from 1797, 1914, 1865, 1900, 1911 and 1914 (https://www.senckenberg.de/wp-content/uploads/2019/10/ Dokument_Hungersteine_und_Untiefen.pdf, last access: 1 June 2020). In the locality opposite Prossen village is a stone that is most often mentioned. Today there are readable inscriptions with dates of 18(?)68 (20 September), 1928 (20 July), 1947 (20 July), 1963 (31 July) and 2003 (17 July). The lowest of these marks relates to 1868 with a correctly marked minimum (in Děčín the minimum was on 19 September). The year 1947 was marked prematurely, which can explain why the mark is the highest (in Děčín the difference between 20 July and the minimum on 11 August is $44 \mathrm{~cm}$ ). The year 1928 is marked quite correctly, although it is not an annual minimum (4 August), but the difference is 
Table 3. Division of HS3 stone and list of marks by ranges.

\begin{tabular}{llrrrr}
\hline Water level ranges & ES (embankment side) & R (ridge) & RS (right side) & LS (left side) & P (platform) \\
\hline (a) $151-175 \mathrm{~cm}$ & & 1963 & - & - \\
(b) $111-150 \mathrm{~cm}$ & $1536,1616,1746,1790$, & - & - & - & $1707,1842,1904,1892$, \\
& $1800,1811,1842,1868$ & & & $1893,1957,1990,2003$ \\
(c) $91-110 \mathrm{~cm}$ & 1921,1934 & - & 1911,1921 & - \\
(d) $71-90 \mathrm{~cm}$ & - & - & $1930,1934,1947$ & 1947 & \\
\hline
\end{tabular}

Table 4. Overview of the annual water level minima on the hunger stones in Děčín.

\begin{tabular}{|c|c|c|c|c|c|c|c|c|c|c|c|c|}
\hline \multirow[b]{2}{*}{ Year } & \multirow[b]{2}{*}{ HD } & \multicolumn{2}{|c|}{ HS2, $H_{1842}$} & \multicolumn{2}{|c|}{ HS1, $H_{1842}$} & \multicolumn{2}{|c|}{ HS3, $H_{1842}$} & \multirow{2}{*}{$\begin{array}{r}H \\
(\mathrm{~cm})\end{array}$} & \multirow{2}{*}{$\begin{array}{r}H_{1842} \\
(\mathrm{~cm})\end{array}$} & \multirow[t]{2}{*}{ Time } & \multirow{2}{*}{$\begin{array}{r}\text { ma.s.l. } \\
\text { (m) }\end{array}$} & \multirow[t]{2}{*}{ Position } \\
\hline & & $\left({ }^{\prime \prime}\right)$ & $(\mathrm{cm})$ & $\left({ }^{\prime \prime}\right)$ & $(\mathrm{cm})$ & $\left({ }^{\prime \prime}\right)$ & $(\mathrm{cm})$ & & & & & \\
\hline 1516 & & - & - & - & - & - & - & 119 & -13.0 & - & 121.25 & $D Z$ \\
\hline 1517 & & - & - & - & - & - & - & 119 & -13.0 & - & 121.25 & $D Z$ \\
\hline 1536 & B & - & - & - & - & - & - & 138 & 6.0 & - & 121.44 & ES \\
\hline 1616 & $\mathrm{~B}$ & - & - & - & - & 5 & 13 & 143 & 11.0 & VII, ??, [2?] & 121.49 & ES \\
\hline 1616 & B & - & - & - & - & - & - & 137 & 5.0 & VII, ??, [2?] & 121.43 & ES \\
\hline 1706 & & - & - & - & - & - & - & 132 & 0.0 & - & 121.38 & $D Z$ \\
\hline 1707 & & - & - & - & - & - & - & 139 & 6.0 & VIII/IX? & 121.45 & $\mathrm{ES}$ \\
\hline 1719 & & - & - & 8.5 & 22.1 & - & - & 154 & 22.1 & - & 121.60 & $H S 1$ \\
\hline 1746 & B & - & - & - & - & ND & - & 150 & 17.0 & VIII/IX? & 121.56 & $\mathrm{ES}$ \\
\hline 1766 & & - & - & 4.5 & 11.7 & - & - & 144 & 11.7 & ca. 10.12.? & 121.50 & $H S 1$ \\
\hline 1782 & & - & - & 8.5 & 22.1 & - & - & 154 & 22.1 & ca. 15.9.? & 121.60 & HS1 \\
\hline 1790 & $\mathrm{~B}$ & - & - & 6.5 & 16.9 & ND & - & 145 & 12.0 & ca. 15.8.? & 121.51 & ES \\
\hline 1800 & & 4.5 & 11.7 & - & - & - & - & 142 & 10.0 & ca. 18.8.? & 121.48 & ES \\
\hline 1811 & B & - & - & - & - & - & - & 139 & 6.0 & 9.8. $(-1)$ & 121.45 & $\mathrm{ES}$ \\
\hline 1834 & B & - & - & 7 & 18.4 & - & - & 150 & 18.4 & $\overline{12.8 . ?}$ & 121.56 & $H S 1$ \\
\hline 1835 & & - & - & 5.5 & 14.3 & ND & - & 146 & 12.0 & ca. 8.9.? & 121.52 & $D Z$ \\
\hline 1842 & $\mathrm{~B}$ & 0 & 0 & 0 & 0 & 0 & 0 & 132 & 0.0 & ca. 25.8.?, [2] & 121.38 & $\mathrm{ES}, \mathrm{P}$ \\
\hline 1868 & $\mathrm{~B}$ & & & & & & & 133 & 1.0 & ca. 26.8.? & 121.39 & $\mathrm{ES}$ \\
\hline 1874 & & & & & & & & 128 & -4.0 & ca. 1.12.? & 121.34 & $T$ \\
\hline 1892 & & & & & & & & 137 & 5.0 & 28.8. $(-\underline{5}),[\underline{2}]$ & 121.43 & $\mathrm{P}$ \\
\hline 1893 & & & & & & & & 135 & 3.0 & $\overline{16.7}$ & 121.41 & $\mathrm{P}$ \\
\hline 1904 & $\mathrm{~B}$ & & & & & & & 112 & -21.0 & $\overline{\text { 23.8. }}(-15),[5]$ & 121.18 & $\mathrm{P}$ \\
\hline 1911 & $\mathrm{~B}$ & & & & & & & 105 & -27.0 & $\overline{\text { 15.8. }}(-\overline{7}),[2]$ & 121.11 & LS \\
\hline 1921 & B & & & & & & & 104 & -29.0 & 2.8. $(-9)^{\mathrm{b}},[\underline{6}]$ & 121.10 & ES, LS \\
\hline 1930 & & & & & & & 8 & 101 & -32.0 & $\overline{\mathbf{1 0 . 9}}(+2)$ & 121.07 & RS \\
\hline 1934 & & & & & & & LS & 73 & -50.0 & 23.6. (0), [3] & 120.79 & $\mathrm{RS}$ \\
\hline 1945 & & & & & & & & $134^{\mathrm{a}}$ & +2.0 & $\overline{9.5 .}(-)$ & 121.40 & $\mathrm{P}$ \\
\hline 1947 & $\mathrm{~B}$ & & & & & & & 68 & -64.0 & $\overline{23.8 .(0),[2]}$ & 120.74 & LS, RS \\
\hline 1957 & & & & & & & & 110 & -22.0 & 8.7. $(\underline{0}),[\underline{2}]$ & 121.16 & $\mathrm{P}$ \\
\hline 1990 & & & & & & & & 110 & -22.0 & 2.9. (0) & 121.16 & $\mathrm{P}$ \\
\hline 1963 & & & & & $P$ & & & $175^{\mathrm{a}}$ & +43.0 & $\overline{(-)}$ & 121.81 & $\mathrm{R}$ \\
\hline 2003 & B & & & & & & & 111 & -21.0 & - & 121.17 & $\mathrm{P}$ \\
\hline 2015 & & & & & & & & 86 & -46.0 & - & 120.92 & - \\
\hline
\end{tabular}

HS1, HS2, HS3 - hunger stones in Děčín; HD - historical documentation; B - mentioned by Brázdil et al. (2015); T - HS in Těchlovice; DZ - HS in Dolní Žleb; $H_{1842}$ - water level relative to the height of the mark of $1842 ; H$ - water level relative to the current Děćín water gauge zero point (120.06 m a.s.l.); time - date of marked minimum, bold underline signifies the exact day engraved in the stone, italics signify the probable timing of the mark creation, (-) days before the annual minimum water stage, $(+)$ days after the annual minimum, ? uncertain value, ?? very rough estimation, $[n]$ the total number of marks in a year, the italic water level values are derived from another object (timing estimated from another gauge); position - placement of DM on ES, RS, LS, P and R sides (Table 4)

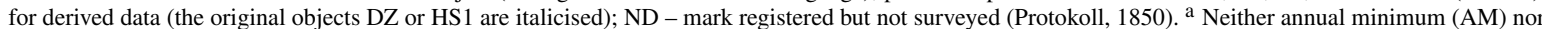
local minimum (LM) but an indication of contemporary water stage. ${ }^{\mathrm{b}}$ The exact AM is denoted by the date of 11 August and contemporary water level ( $a$ value) without any mark. 
Table 5. Marks on a hunger stone in Dolní Žleb surveyed in 1842 (Protokoll, 1842).

\begin{tabular}{|c|c|c|c|}
\hline \multirow[b]{2}{*}{ Year } & \multicolumn{2}{|c|}{$H_{1842}$} & \multirow{2}{*}{$\begin{array}{l}H_{\mathrm{DE}} \\
(\mathrm{cm})\end{array}$} \\
\hline & "I & $(\mathrm{cm})$ & \\
\hline 1516 & -5 & -13 & $119.0^{*}$ \\
\hline 1517 & -5 & -13 & $119.0^{*}$ \\
\hline 1615 & ND & - & - \\
\hline 1616 & 2 & 5.2 & 137.2 \\
\hline 1634 & ND & - & - \\
\hline 1706 & 0 & 0 & 132.0 \\
\hline 1842 & 0 & 0 & 132.0 \\
\hline \multicolumn{4}{|c|}{$\begin{array}{l}H_{1842} \text { - DM water level relative to the } \\
\text { level of DM1842; } H_{\mathrm{DE}}-\text { water level } \\
\text { relative to the current Děćín water gauge; } \\
\text { ND - mark registered but not surveyed } \\
\text { (Protokoll, 1850). * Report only (Neue } \\
\text { Schriften, 1845). }\end{array}$} \\
\hline
\end{tabular}

Table 6. Hunger stones detected in Dolní Žleb by Randák (2015, 2017a).

\begin{tabular}{|c|c|c|}
\hline No. & Kilometre & Description \\
\hline 1 & 730.550 & "1904 (15.8.)" \\
\hline 2 & 730.780 & “1892", "E. Dittrich" \\
\hline 3 & 730.82 & “1892”, "Ed. Ditr." \\
\hline 4 & 730.830 & “1892”, “1893”, “E. H.”, “E. D.”, heart motif \\
\hline 5 & 730.910 & “1921” (“F. H.”?) \\
\hline 6 & 731.160 & "1892", "F. Hobe" or "Hoke"? \\
\hline 7 & 731.260 & $\begin{array}{l}\text { "1842”, “1868”, “1892”, “1904”, "V. Witr” ?, } \\
\text { "V. Hobe" }\end{array}$ \\
\hline 8 & 731.180 & "HF”, “1892”, “1935” \\
\hline 9 & 731.415 & “2015 13.8." " \\
\hline 10 & 731.420 & 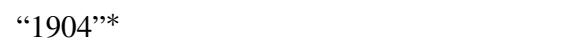 \\
\hline 11 & 732.010 & $\begin{array}{l}\text { "1904"* (at the house of the former } \\
\text { ferryman H. Strasser) }\end{array}$ \\
\hline
\end{tabular}

$?$ - the inscription is unclear.

* Underwater at the time of exploration.

very small. On another stone there are newer data of 1963 , 2003 and 2015.

\subsubsection{Hunger stone in Pillnitz}

None of the commissions (1842, 1850 and 1858) found any remarkable stones there. However, the Pillnitz site has been, next to Dresden and Meissen, a place of important flood level observations as early as 1736 (Pötzsch, 1784). There is a clear inscription from 1778 , which is probably not the minimum water level (see discussion). The marked HS includes minima: 1893, 1904, 2003 and 2018.

\subsubsection{Hunger stones in Pirna}

This was located near a small gate at the navigation control point, but this situation no longer exists. Nearby, there was a
Table 7. Hunger stones detected in Hřensko by Randák (2015).

\begin{tabular}{ll}
\hline No. & Description of the hunger stone \\
\hline 1 & "5.8. (19)?28" \\
2 & "Kladno 1950" \\
3 & "K.R. 10/9. 1874" \\
4 & "H. Rausch 1904" \\
5 & ?, "W.W F.D.N" \\
6 & "1911", "1919", "3. 8. 1911 ER WK PP" \\
7 & "FC 1911" \\
8 & "1892" \\
9 & "1934" \\
10 & "1928", "1950", "GW" \\
11 & "N 1927" \\
12 & "1927" \\
13 & "1928", "1855", many other inscriptions \\
14 & "1904/22.7", "1934", many other inscriptions \\
& below the water level \\
\hline
\end{tabular}

$?-$ the inscription is unclear.

transverse dam opposite to which a flat stone with engraved marks could be seen. According to the Protokoll (1842), the marks of 1616, 1706, 1707, 1746, 1834 and 1835 were registered and surveyed (the other marks were illegible). The water level at that time was $6^{\prime \prime}(13 \mathrm{~cm})$ above the inscription "Waserbau Direction 1842". At the navigation office there was a water gauge placed on the retaining wall for low water levels (up to 4 Saxon ell units) continuing on the building (the higher part). The minimum of 1842 was at the level of -1 ell $22.5^{\prime \prime}(-108 \mathrm{~cm})$ below the zero point. The water level during the measurement in 1842 (on 8 September) was at a height of -1 ell $16.5^{\prime \prime}(-95 \mathrm{~cm})$. The difference between the marks of 1616 and 1842 was $5^{\prime \prime}$, as in Děčín. In 1850 (on 27 September), the water level of -1 ell $(-57 \mathrm{~cm})$ was registered. The measurement was carried out at that time at a water level $0.38 \mathrm{~cm}$ higher than in 1842 . The previously described marks were as much as $51 \mathrm{~cm}$ below the water level. Therefore, there is no reference to a hunger stone here. In 1874 (at a time of catastrophic drought), a new water gauge with a zero point at 110.94 ma.s.l. was set up; if the zero point of the original water gauge was the same, the minimum in 1842 was at $109856 \mathrm{~m}$ a.s.l. According to photographs of the current state, the inscription from 1842 and the marks of 1707 and 1790 were preserved, and the marks of 1616 and 1746 were not found. In addition, there are readable marks from 1782 and 1811. After 1842, the marks from 1859, 1863, 1868, 1873 and 1892 were added. The newer markings (1904, 1947 and 1952) are probably lower with regard to later channel dredging, while the marks of 1963 and 2003 were higher after the Vltava cascade was opened. On the stone there are five scales for particular years, including 1707, 1904, 1911, 1842 and 1952, showing more minima in a year. In 2018, the stone was documented by 
Table 8. Marks on a hunger stone in Pirna surveyed in 1842 (Protokoll, 1842).

\begin{tabular}{crrr}
\hline & \multicolumn{2}{c}{$H_{1842}$} & \multirow{2}{*}{$H_{\mathrm{DE}}$} \\
\cline { 2 - 3 } years & $\prime \prime$ & $(\mathrm{cm})$ & $(\mathrm{cm})$ \\
\hline 1616 & 5 & 13.0 & 145.0 \\
1706 & 11 & 28.6 & 161.0 \\
1707 & 9 & 23.4 & 155.4 \\
1746 & 10 & 26.0 & 159.0 \\
1834 & 9 & 23.4 & 155.4 \\
1835 & 9 & 23.4 & 155.4 \\
1842 & 0 & 0.0 & 132.0 \\
\hline$H_{1842}-$ DM water level relative to the \\
level of DM1842; $H_{\mathrm{DE}}-$ water level \\
accommodation to present Děčín gauge.
\end{tabular}

LfULG (Sächsisches Landesamt für Umwelt, Landwirtschaft und Geologie), Dresden, experts, and the results were presented at a seminar on flood marks and minimum water levels in Jena in March 2019. There was an exchange of information between the CHMI and LfULG. We provided a sketch of the stone in Pirna, which was used to reconstruct the engraved signs that are exhibited today in the LfULG building in Dresden (https://www.thueringen.de/th8/tlug/presse_ und_service/veranstaltungsmaterial/2019/01/index.aspx, last access: 1 May 2019). The second, newer stone in Pirna has a mark from 1904.

\subsubsection{Hunger stones in Dresden}

None of the commissions (1842, 1850 and 1858) mentioned any remarkable stones. Nevertheless, pictures are published of hunger stones in the Kotta locality with an inscription of the year 1630 (it is possible that it rather concerns 1636). We have no views regarding the credibility or existence of these stones. In the Radebeul locality, there is probably a millstone with an inscription of the year 1911. In the Laubegast locality, there are stones with inscriptions of the years 1892, 1893, 2003 and 2013. In the Tolkewitz locality, there is a stone with a 2016 mark. In the Augustbrücke cross section, a low water level of 1705 was indicated (Pötzsch, 1874), and now there is also a mark from 2018.

\subsubsection{Hunger stone in Meissen}

We learned about the hunger stone from older literature of the 18th century. None of the commissions $(1842,1850$ and 1858 ) found any remarkable stones. The only report on the flood marks is conveyed in literature. Ursinus (1790) mentions the dry year of 1746 (see Tables 4, 9, 10) and the discovery of various stones in the Elbe River. In Meissen year markings were found on one of these stones, indicating a dry year in 1654 .

\subsubsection{Hunger stone in Strehla}

The Protokoll (1842) describes a hunger stone (a rock rising from the river) on the right bank of the Elbe with minima from 1718, 1746, 1790, 1800, 1834 and 1835. The height of 1800 was $5^{\prime \prime}(12.7 \mathrm{~cm})$ below the then current water stage. The water level at the Strehla water gauge in 1842 was -1 ell $15^{\prime \prime}(-91 \mathrm{~cm})$; in Riesa, the water level was -2 ells $(-113.2 \mathrm{~cm})$ and in 1850 only $-6^{\prime \prime}(-14 \mathrm{~cm})$ (Protokoll, 1842, 1850). This stone was probably removed, while another rock block called Nixstein, formerly dreaded by boatmen, remained there (at the left bank), where a depth of $160 \mathrm{~cm}$ was measured in 1850. A somewhat problematically placed mark was made here in 2018 (https://www.saechsische.de/ eine-hungermarke-fuer-den-nixstein-4001437.html, last access: 2 July 2020).

\subsubsection{Hunger stone in Schönbeck near Magdeburg}

On 29 May 1858 the committee recorded the water level at $4^{\prime} 5^{\prime \prime}(139 \mathrm{~cm}$ in accordance with the 1827-1888 Magdeburg series indicating the water stage at $141 \mathrm{~cm}$ ). A board with the inscription marking 29 August 1904 was removed from the river bank and placed in a museum.

\subsubsection{Notes on the creation and specific details of the marks of water minima}

There are always fewer records of low water levels (if any) than marks of high water stages, the only exception possibly being the sandstone Elbe valley between Děčín and Pirna. It is more difficult to make a mark of the minimum water level than to make a flood mark due to the following reasons:

1. It is and it has always been difficult to estimate the correct instant of reaching the minimum level. More demanding inscriptions were probably made in advance. The designated place was probably enclosed by a small barrier beforehand so that the mark could be completed at a time when it was clear that the minimum had been reached; i.e. when the water was rising. Therefore, the logical moment of making the minimum mark is after the minimum has subsided (in reality, $1-15 \mathrm{~d}$ before the annual minimum level, these DM levels were engraved; see Table 4). However, it is not clear whether this was a local or annual minimum.

2. In some years, the level fell even lower. The exact date is given, or a range of water levels for a given year is made, such as in Děčín for the years 1904, 1921, 1930, 1934 and 1957. It is also surprising to note the range for the year 1707 in Pirna as otherwise the low water mark might have been rather doubtful. The mark of 1842 in Pirna seems to have a different meaning, being the actual water stage in feet. 
3. The minimum markings are often made upside down (made from the upper side of the stone) while some were made while standing in the water or at a lower position (orientated normally). Therefore, the engraved lines in such cases are not below the date (in the graphic sense) but above it, thus closer to the water surface (in Děčín, for instance, these DMs: 1536, 1707, 1892, 1893, 1904, 1911 and 1934).

4. The marks are completed by monograms (see Pažourek, 1995). The second oldest mark, from 1616, was completed by the initials F. L., from 1707 by the initials M. L. R., and from 1746 by the initials H. M. L., so there is a possibility that they concern members of one family. Later, in 1790, there are the initials H. G. T., in 1800 A. I., in 1811 and 1842 W. E., and the designation is missing for 1821. Another change is the first year corresponding to the instrumental series, so in 1868 the initials are F. H.; however, in 1892 and relisted in 1893, the designation contains the initials $\mathrm{U}$. E. The originator of other marks was probably the popular Franz Mayer, who is the author of the 1904, 1911, 1921 and perhaps even the 1930 markings. In connection with the 1904 mark, the popular inscription "Wenn du mich siehst dann weine" (if you see me, you will weep) was created. The last mark until the relocation of the original German population comes from 1934. The originator of the first post-war mark was a Horák. It is therefore evident that signs of low water levels were accompanied by specific habits.

5. There are overlapping inscriptions. In view of the place of origin and various perhaps personal, local, national and even commercial considerations, there were exceptional cases of overlapping inscriptions. Thus the 1904 mark, perhaps made by a certain Rotsch, was obscured by the second inscription, "Wenn du mich siehst dann weine, Fr. Mayer", relating to 1911.

\subsection{Assessment of identified water level minima from 1516 to 2018}

\subsubsection{Decade frequencies of $1500-1800$}

There are no direct water level observations for comparison purposes in the 1516-1727 period. According to Brázdil et al. (2013, 2015), the 1511-1520, 1531-1540 and 1631-1640 periods had a higher decade frequency $(n=6$ per decade) of drought reports. The coincidence of very low-lying DMs $(H=110-140 \mathrm{~cm})$ in $1516,1517,1536,1616$ and 1636 with these 3 decades is evident from Fig. 5. Brázdil et al. (2015) selected several periods of intense drought for detailed processing on the basis of an analysis of documentary sources. The years 1534, 1536, 1540 (Wetter et al., 2014), 1590 and 1616 were selected as extreme cases. In two cases (1536, 1616) there are documented DMs, but three are missing.
Even so, we can consider our documentation a good match. This result supports the credibility of the 1516 and 1517 marks, which have not been preserved or not yet been documented, which we only know from the Neue Schriften (1845) and the report by Focke (1879). On the other hand, from 1536 to 1616 , no record of water level minima exists in the set for 80 years, although minima of both extremes in 1540 and 1590 can be expected. From this period, we can mention only the height of 1541 from the Rhine basin. However, in the $1560-1600$ period, a very high frequency of floods is documented with a recurrence period of 10 years or more $\left(\geq Q_{10}\right)$ (Elleder, 2015). Although the dry period does not exclude significant floods at all, in this case it concerned more frequent cases of floods of approximately $Q_{20}$. We can consider it a period with an average drought occurrence, where according to monthly rainfall indices at least the index -2 (very dry month) occurred in 2 or more consecutive months in 1555 (3 months), 1561 (2), 1562 (2), 1571 (3), 1581 (2), 1589 (2) and 1590 (4). The index -3 (extremely dry month) occurred only once in 1569 (May) and in the dry year of 1590 for 2 months (July and August) (Brázdil et al., 2013, 2015).

From 1636 to 1707 , i.e. for 70 years, there are no marks of minimum water levels. Brázdil et al. (2013) pointed out that the three decades of 1641-1650, 1661-1670 and 1671-1680 had a minimum decade occurrence of drought reports (two cases per decade). Moreover, it is a period of the Maunder Minimum (Eddy, 1976), i.e. the 1640-1720 period, probably the most intensive period of the Little Ice Age (LIA).

\subsubsection{The Magdeburg series minima of $1727-1880$}

Since 1727, we have been able to identify the minima in the years highlighted in Fig. 6 with the help of the Magdeburg series. A very good time coincidence is apparent for 1746 , 1766, 1782, 1790, 1800, 1811, 1835, 1842, 1858 and 1874. The year 1868 is missing, thus there is no representation of a deviating minimum in Magdeburg; however, there is a significant mark later in 1869 . The year 1766 represents the only significant winter minimum which was marked on hunger stones. However, the winter minima of 1818, 1823 and 1862 are missing.

The water level DM minima are plotted on the water level scale of the current water gauge in Děčín. A coincidence regarding the water level (1746) is completely random (Fig. 6). However, there is a noticeable difference in the trend of annual lows of both series. We also emphasised the effect of the overall minima, so the graph also separates the winter minima, which show a downward trend, for example, just before 1746.

It is worth noting that the winter minimum of 1823 is not shown on the Elbe HSs, but in view of the timing it corresponds to the low water levels of the Rhine. The only significant summer minima that are not documented on the HSs in the Czech part of the Elbe are around 1760, 1858 and 1878 (see the Discussion). 


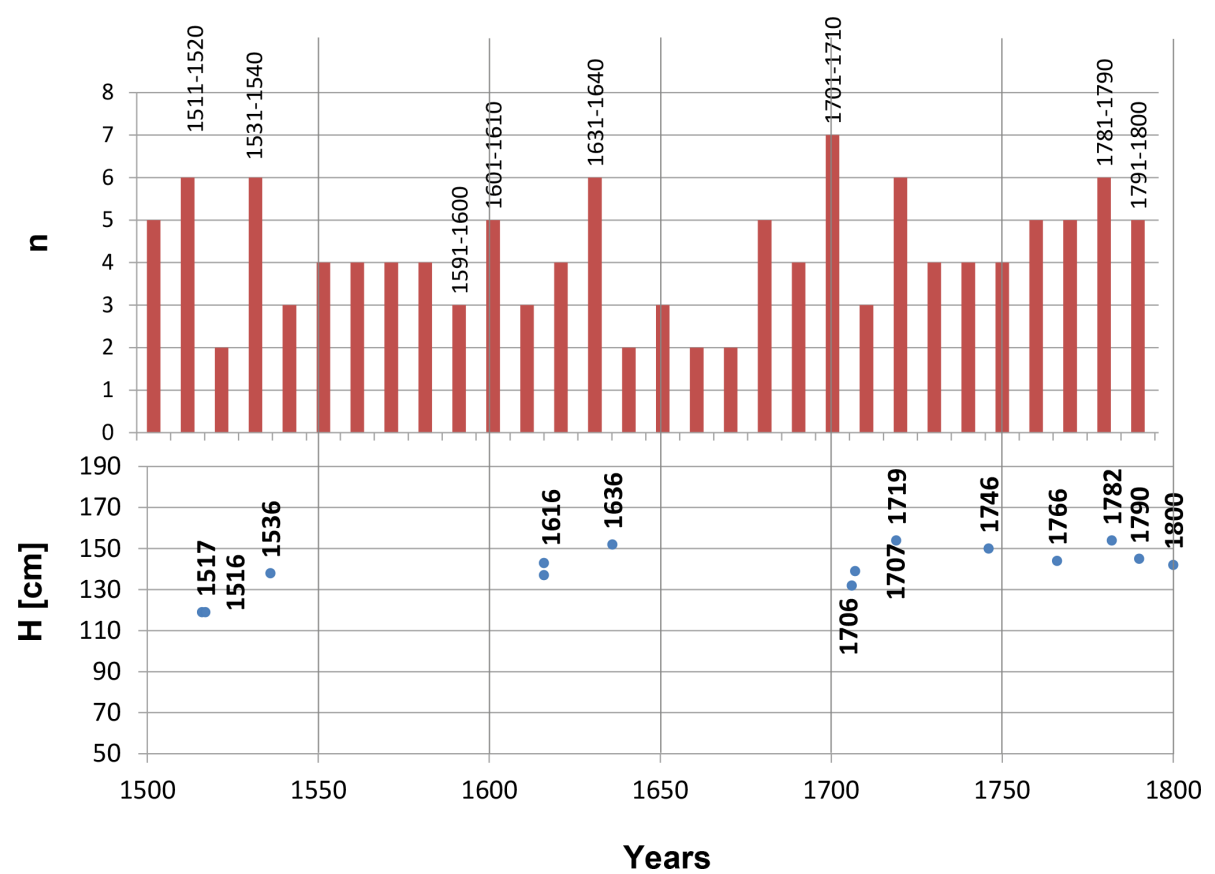

Figure 5. Verification of marks of 1500-1800 according to the decade frequency of drought reports by Brázdil et al. (2013). $n$ is the decadal frequencies of droughts, and $H(\mathrm{~cm})$ is the water level of the DM.

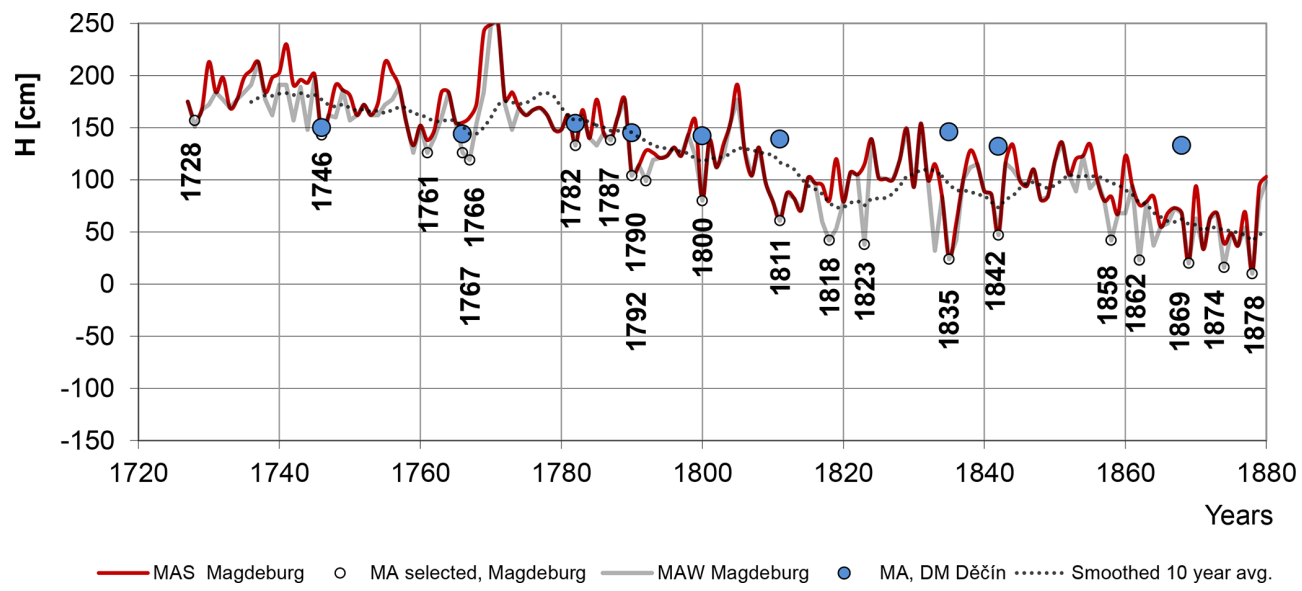

Figure 6. Verification of marks in the period of 1727-1800 according to the annual (MAW, grey line) and summer (MAS, red line) minima of the Magdeburg 1727-1800 series with annual minima identified (and derived) from the marks on the HS3 hunger stone in Děčín (MA, blue circles).

\subsubsection{The Děčín series minima of 1851-2018}

If we compare the results with the Děčín series, i.e. with direct measurements in the vicinity of the HS3 hunger stone, the deviations of the marked and measured annual values are minimal. Until 1957, there are 11 year lows (not counting local minima) which we can evaluate, and eight of them have a deviation of less than $4 \mathrm{~cm}$. A result of less than $5 \mathrm{~cm}$ is detected for the marks from $1911(+7 \mathrm{~cm}), 1921(+9 \mathrm{~cm}), 1930$ $(+5 \mathrm{~cm}), 1947(-6 \mathrm{~cm})$ and $1957(+5 \mathrm{~cm})$ (see the graph in Fig. 7). In 1921, the local minimum was correctly marked; the annual minimum was not marked. The minima marked later, in 1963, 1981 (missing in the figure), 1990 and 2003, are not as important as the older extremes. In their origination, modern anthropogenic influences and partial misunderstandings of older traditions are manifested. This also applies to the prematurely made mark in Těchlovice. The 2003 mark is made correctly.

In conclusion, we can state a good match of the minima detected, which, moreover, are mostly representative of the largest extremes. However, this is not entirely true, as some 

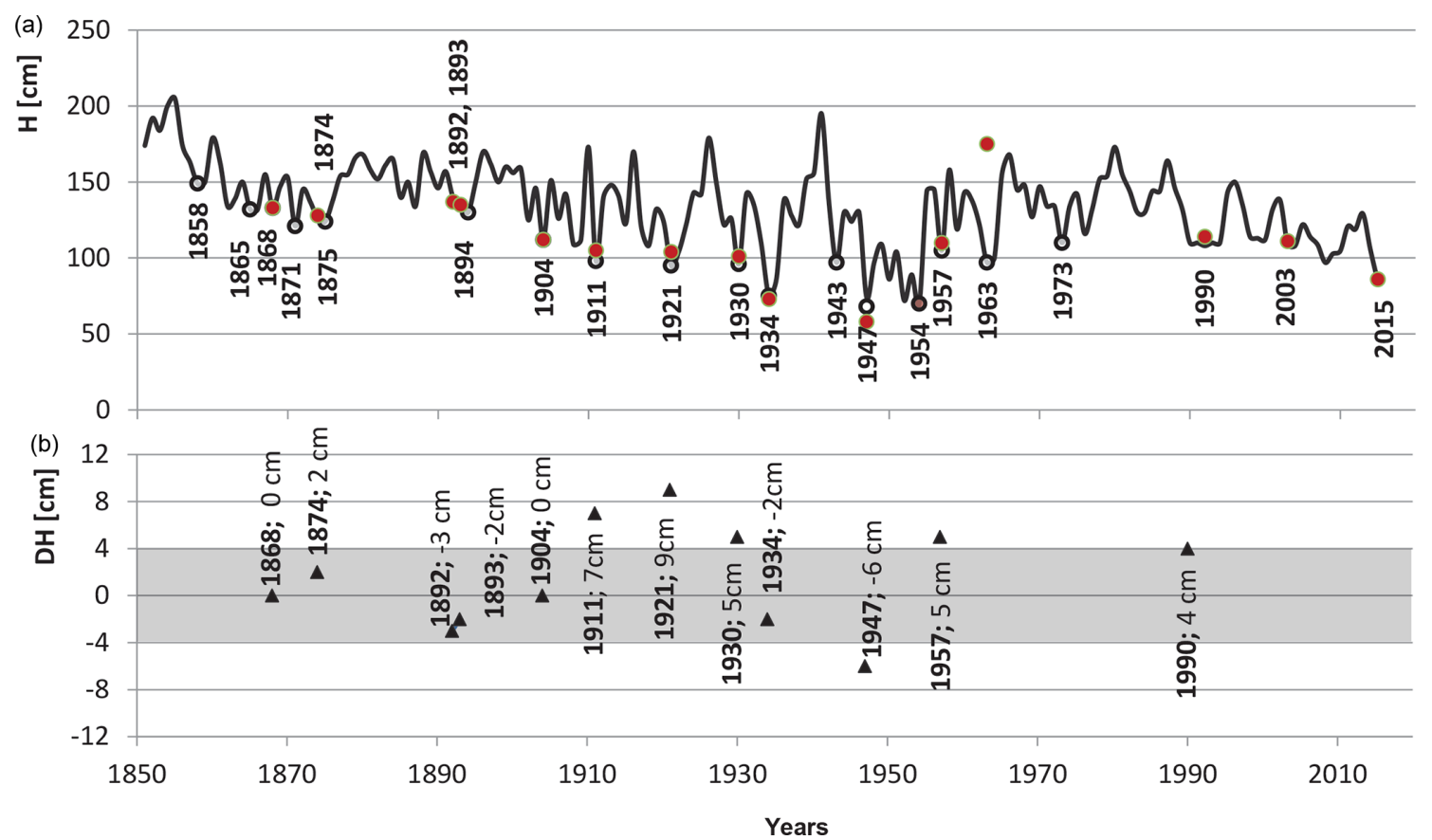

Figure 7. Coincidence of annual water level minima at the Děčín station (grey circles) and altitudes measured on the HS1 and HS3 hunger stones in Děčín and Dolní Žleb (red circles). $H$ is the water level. DH is the deviations of the marked and measured annual values which are highlighted in the lower part of the graph. The precisely marked height (PMH) with deviations of $0-4 \mathrm{~cm}$ is highlighted in grey, and the outstanding marks are approximately marked heights (AMH) with deviations of $4-8 \mathrm{~cm}$ or more.

years such as 1540, 1590 and 1761 are missing. This is a great motivation for the next stage of work.

\section{Discussion}

\subsection{Credibility of minimum flow marks}

There is no need to doubt the credibility of the low water level marks in Děčín from 1868 to 1957. When interpreting them, however, it is necessary to know the described changes: whether they are changes in the channel or flow rate enhancement due to the Vltava cascade. These are annual or local minima marked with the greatest possible care. It is also obvious that older marks in the 19th and 18th centuries were made in the same way and with the same intentions. Can this claim be extended to the past, i.e. to the 17th and 16th centuries, and is this finding valid for other hunger stones both in Bohemia and Saxony?

It would probably be appropriate to prove the connection of the high marks in Děčín, Dolní Žleb, Schmilka and Pirna. However, when verifying the relationship between Pirna and Děčín, we can compare only four concurrent records. These are the years 1616, 1707 and 1842. Since we use the relative difference to the water stage in 1842 , we can only compare the three remaining heights of 1616, 1707 and 1746. The relationships of 1616, 1707 and 1842 are linear; the water stage in 1746 is somewhat different, where the difference from the expected value is more than $10 \mathrm{~cm}$. Perhaps only a local minimum (LM, not AM) was marked in Pirna. However, we only use the published data from 1842 and 1843, and it is not entirely certain that the commissioners found and surveyed the lowest mark for a given year. Verification is still difficult; we do not see this mark on the current stone in Pirna-Oberposta.

We can recommend further field surveys in future (the next one especially in Dolní Žleb) and the levelling and scanning of other objects, especially the stone in Pirna. For a detailed analysis and a search for remnants of older marks, it is impossible to rely solely on photographic documentation. Comparatively older photographic material (Fig. 8) and detailed inspection of scanned 3D objects are required.

Since we can trust DM epigraphic sources, the only thing that remains is to point out other published sources from 1842 to 1843 . These are compilations of the measurements by the then commissioners/hydro technicians and possibly subsequent processing by the Statistical Office of the Kingdom of Saxony or the Patriotic Economic Society of the Czech Kingdom. They point to other low levels that we expected and that could not be verified. This includes, for example, the height of 1590. A report based on the results of the commission in 1842 and therefore the Protokoll (1842) appeared in Adler Magazine (no. 13, dated 13 January 1843). There, the water level is reported in Dresden as 2 ells $3^{\prime \prime}$ below the zero point and a series of low levels, from which we chose those that could not be documented in situ or verified 


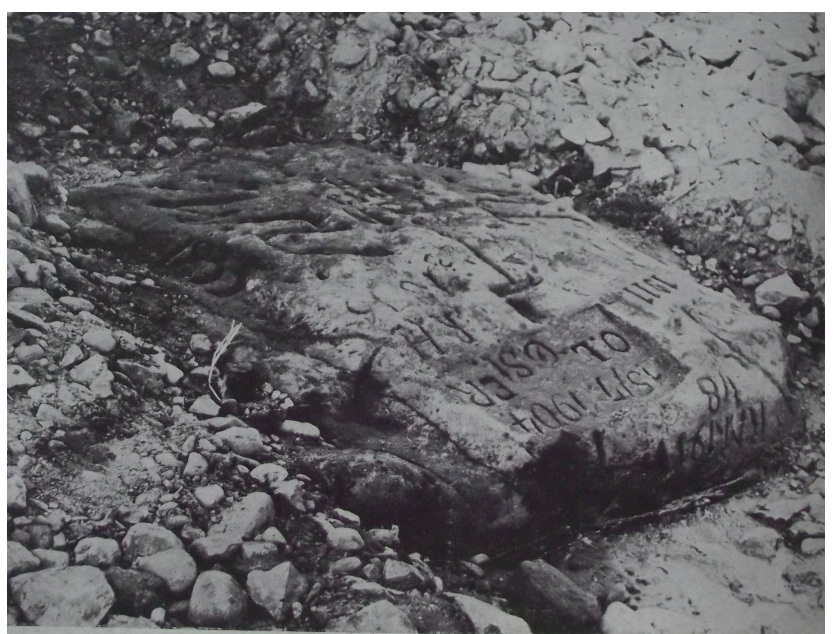

Figure 8. Picture from Český svět magazine, no. 51, dated $25 \mathrm{Au}-$ gust 1911. It shows a completely unknown hunger stone. The following years are engraved: 1835, 1904, 1911, 1873 and 1(?)76 $(1576,1876$ or 1516 ?). This picture was found in the National Museum archive by Zvonimír Dragoun. The locality is unknown, and the existence is unverified.

in scientific literature: $1590,1634,1635,1637,1660,1666$, 1669, 1678, 1681, 1686, 1705, 1716, 1718, 1726, 1761, 1789 and 1794. Another remarkable source is an article in the Prague summary report Encyklopädische Zeitschrift des Gewerbewesens (3rd edition of the new series from 1843, Statistik der Gewerbe und Handel, pp. 86-93), which draws on the Preussisch Staat Zeitung no. 354. The same data were published in a more popular way in educational journals such as Das Pfennig Magazin (no. 10, 11 March 1843). The exact heights published there are given in Table 9. The Gewerbe Blatt für Sachsen (no. 5/1843, https://digital.slub-dresden.de/ werkansicht/dlf/69679/1/, last access: 3 July 2020), a technical magazine, states in the explanatory note that the minimum mark of 1590 was indistinctly recognised on an unnamed hunger stone or object in Rathen between the HS in Königstein and the HS in Stadt Wehlen-Pötzcha. It is not clear whether the mark was too deep or was unreadable, and its height was therefore not stated.

If we take this source into account and we combine these data with the data already presented, we find a slight shift in some places, but the overall picture and trend confirm information on the minima of water levels from hunger stones in Bohemia. Another source is the report of the Patriotic Economic Society (Neue Schriften, 1845), where a forester and observer of the Děčín-Podmokly station gave the exact height of the marks (Table 10). This is partly a compilation of the heights from Děčín and Dolní Žleb; the data are very similar or the same (1616, 1707, 1746, 1811, 1835 and 1842). Differences of more than $8 \mathrm{~cm}$ are shown only by the DM of 1766 , and minor differences are seen in the years 1782,1790 and 1800 . However, there are also data for 1516,1517 and
1834. To complement the Děćín data, the minima of 1516 and 1517 were mainly used. We assume that, as a forester and a meteorological observer, Adam Seidel could supplement the report of the commissioners (who had only a limited time to survey) from his own examinations in Dolní Žleb and Děčín, where he lived. The years 1516 and especially 1517 were very dry, as evidenced by contemporary descriptions in the Old Czech Chronicles (SLČ, 1941) in particular, describing rather meteorological and phenological parameters of drought (e.g. harvest occurring as early as on 29 June).

\subsection{Bad and doubtful markings}

In the promotional photographs issued as postcards, we can find supposed minimum marks that do not correspond to the reality (correction in parentheses) such as the years 1745 (1746) and 1858 (1868). The often published postcard with a lady in a hat by Ernst Rennert (as in Brázdil et al., 2015, 2019a) and an article in the regional anthology (Pažourek, 1995) indicate an inscription from 1417 in the left part of the plateau at the river. Is this possibly a misinterpretation or is this a complete forgery? In these places, there is now an inscription from 2003, but there is no indication that there is any mark, not to mention that the date would necessarily have been made using Roman numerals. There were once completely or partially wiped out inscriptions of the minimum of 1904 and the inscription "1904 Weh" ("misery" or "suffering"). These inscriptions have virtually disappeared.

In the river side of Pillnitz Castle, there are signs including a year marking of 1778. By comparison with the mark heights in Magdeburg and the descriptions in documentary sources, it can be considered rather to mark the year of repairing the castle in 1778 or even the anniversary of its founding in 1718. But then it should be marked as 1718 .

\subsection{Probable connections between flood marks and hunger stones in Pirna and Děčín}

It is remarkable that we find virtually the same tradition and the same DMs in Děčín and Pirna on the Saxon and the Czech sides. At that time, from the 13th to the beginning of the 15th century, today's Saxon Pirna was part of Bohemia. In 1432 the towns were hit by a catastrophic flood, the height of which is marked in Děčín next to the RG1 rock water gauge. In 1515, Děčín became the property of aristocratic families from neighbouring Saxony, first of the lords of Salhausen and from 1534 onward of Bünau (Schattkowsky, 2003). Until 1628 , i.e. for 94 years, this family was in possession of the Děčín and Weesenstein estates in the vicinity of Pirna. At that time, the oldest identified low-level signs of 1536 and 1616 were made on the HS3 stone in Děčín. The low water levels of 1516 and 1517 are only documented in literature (Neue Schriften, 1845), i.e. at the time of the Salhausens. With the beginning of the Thirty Years' War (1618-1648) and the recatholicisation of Bohemia in 1626, Pirna became the centre 
Table 9. An overview of the Saxon DM-type sources (edition of the new series from 1843, Statistik der Gewerbe und Handel, pp. 86-93).

\begin{tabular}{|c|c|c|c|c|c|c|c|}
\hline \multirow[b]{2}{*}{ Year } & \multicolumn{3}{|c|}{ Saxony $H_{1842}$} & \multirow{2}{*}{$\begin{array}{r}\text { Pir } H_{1842} \\
(\mathrm{~cm})\end{array}$} & \multirow{2}{*}{$\begin{array}{r}\text { Sch } H_{1842} \\
(\mathrm{~cm})\end{array}$} & \multirow{2}{*}{$\begin{array}{l}\text { Str } H_{1842} \\
(\mathrm{~cm})\end{array}$} & \multirow{2}{*}{$\begin{array}{r}H_{\mathrm{DE}} \\
\text { m a.s.l. }\end{array}$} \\
\hline & $\left({ }^{\prime \prime}\right)$ & $\left({ }^{\prime \prime \prime}\right)$ & $(\mathrm{cm})$ & & & & \\
\hline 1615 & 17.5 & & 45.7 & - & - & - & 177.7 \\
\hline 1616 & 3.5 & 0.5 & 9.1 & 13 & - & - & 141.1 \\
\hline 1635 & 9 & & 23.5 & - & - & - & 155.5 \\
\hline 1636 & 8 & & 20.9 & - & - & - & 152.9 \\
\hline 1705 & 11 & & 28.7 & - & - & - & 160.7 \\
\hline 1706 & - & - & - & 28.6 & - & - & - \\
\hline 1707 & 4.5 & 0.5 & 11.8 & $23.4, \mathrm{E}$ & - & - & 143.8 \\
\hline 1718 & - & - & - & - & - & ND & - \\
\hline 1746 & 10 & & 26.1 & 17 & - & ND & 158.1 \\
\hline 1761 & 5.5 & 0.5 & 14.4 & - & - & - & 146.4 \\
\hline 1782 & 11 & & 28.7 & E & - & - & 160.7 \\
\hline 1789 & 14 & & 36.5 & - & - & - & 168.5 \\
\hline 1790 & 6 & & 15.7 & - & - & ND & 147.7 \\
\hline 1794 & 11 & & 28.7 & - & - & ND & 160.7 \\
\hline 1800 & 8 & & 20.9 & E & - & - & 152.9 \\
\hline 1811 & 6 & & 15.7 & E & 7.5 & - & 147.7 \\
\hline 1811 & 6.5 & 0.5 & 17.0 & $\mathrm{E}$ & - & - & 149.0 \\
\hline 1834 & 8 & & 20.9 & 23.4 & - & ND & 152.9 \\
\hline 1835 & 8 & & 20.9 & 23.4 & - & ND & 152.9 \\
\hline 1842 & 0 & & 0 & $0, \mathrm{E}$ & 0 & - & 132.0 \\
\hline
\end{tabular}

Saxon inches ["] and line units ["' $]$; Pir - Pirna HS; Sch - Schmilka HS; Str - Strehla HS; $H_{1842}$ - DM water level relative to the level of DM1842; $\mathrm{E}$ - existence is verified; $H_{\mathrm{DE}}$ - water level relative to the current Děčín water gauge; ND - mark registered but not surveyed.

of Czech exiles. It is evident that Děčín and Pirna are bound by one river, chain-boat navigation and partly by common history. It is therefore not surprising that we find an analogy in the area of the documentation of flow minima.

\subsection{Relationship between the Rhine and Elbe minima}

The alluvial-pluvial regime of the Rhine predetermines the seasonality of the Rhine minima, which occur rather in autumn and winter. This is mostly later than on the Elbe, where there are mostly summer minima. The very dry period of 1536-1541 is defined particularly by the Elbe and Rhine minima (Table 11a, b). The mark of 1654 in Meissen is known only from literature, in which there are also a number of reports from the Rhine basin. An almost perfect concurrence is represented by the minima of 1766 and 1767 . The very warm and dry period of 1790-1794 was evident in both river basins. The lows also coincide in 1800 and 1858 . In the Rhine basin, the drought was more significant. In the Elbe River basin, the catastrophic flood changed the situation at the end of July and beginning of August, which affected the upper Elbe basin and mainly the Krkonoše and Krušné Ore Mountain areas (Elleder, 2015).

A comparison of the duration of the tradition of making minimum markings in the Rhine and Elbe basins does not clearly indicate a longer tradition in either area. What is more interesting is a graphical overview of data from the
Czech and Saxon DM sources (Fig. 9). It is apparent that the downward trend pointed out by reputed geographers and water managers (Burghaus, Grebenau, Wex, Harlacher and others) in the measured series has been apparent since about 1746, even at the lows recorded on hunger stones. In the case of Děčín, it is clear that during the coldest period of the LIA, the Maunder Minimum (Eddy, 1976) could have had a positive effect on the Elbe runoff, although, for example, Ogurtsov (2019) illustrates an even deeper minimum in the first half of the 15 th century.

Unfortunately, the marks of 1516 and 1517 and their positions are known only through the testimony of Adam Seidl of Děčín and from an indication in the Protokoll (1842). However, the positions of the 1536 and 1616 marks increase their credibility. The downward trend since 1746 in Děčín cannot be explained only by the hypothetical deepening of the profile or as a result of the artificial shortening of the Elbe in the case of Dresden and Magdeburg. The fact that the runoff may have been comparable to the period after 1842 and even lower before the onset of the Maunder Minimum may be useful knowledge about the status of the basic flow and the status of groundwater. In the case of the Rhine, we have very little data available. The existing information, however, does not contradict previous considerations. Again, there are two important time points, the years of 1541 and 1750 . The interpretation of other reports on hydrological drought from the Maunder Minimum period is a matter for future studies. 
Table 10. Compilation of the Czech DMs (Neue Schriften, 1845).

\begin{tabular}{|c|c|c|c|c|c|}
\hline \multirow[t]{3}{*}{ Year } & \multicolumn{3}{|c|}{$H_{1842}$} & \multirow{2}{*}{\multicolumn{2}{|c|}{$\begin{array}{l}\text { Comparison with objects } \\
\text { on the Czech side }\end{array}$}} \\
\hline & \multirow[t]{2}{*}{$\operatorname{Inch}\left({ }^{\prime \prime}\right)$} & \multirow[t]{2}{*}{ Line unit $\left({ }^{\prime \prime \prime}\right)$} & \multirow[t]{2}{*}{$\mathrm{cm}$} & & \\
\hline & & & & $\begin{array}{r}H_{1842} \\
(\mathrm{~cm})\end{array}$ & $\begin{array}{l}\text { Object HS and } \\
\text { (sources) }\end{array}$ \\
\hline 1516 & -5 & & -13.1 & -13.0 & $\mathrm{DZ},(\mathrm{NS}, \mathrm{P})$ \\
\hline 1517 & -5 & & -13.1 & -13.0 & DZ, (NS) \\
\hline 1616 & 4 & 4 & 11.3 & 11.0 & HS3, (L) \\
\hline 1707 & 3 & 4 & 8.7 & 6.0 & HS3, (L) \\
\hline 1746 & 6 & 6 & 17.0 & 17.0 & HS3, (L) \\
\hline 1766 & 10 & 2 & 26.5 & 11.7 & $\mathrm{HS1}$, (P) \\
\hline 1782 & 6 & 8 & 17.4 & 22.1 & $\mathrm{HS1},(\mathrm{P})$ \\
\hline 1790 & 6 & 6 & 17.0 & 12.0 & HS3, (L) \\
\hline 1800 & 6 & 10 & 17.9 & 10.0 & HS3, (L) \\
\hline 1811 & 3 & 1 & 8.0 & 6.0 & HS3, (L) \\
\hline 1834 & 7 & 0 & 18.3 & 18.3 & $\mathrm{HS1}$, (P) \\
\hline 1835 & 6 & 0 & 15.7 & 14.4 & HS1,(P) \\
\hline 1842 & 0 & 0 & 0.0 & 0.0 & $\mathrm{HS} 3,(\mathrm{P})$ \\
\hline
\end{tabular}

Austrian inches ["] and line units ["' $] ; H_{1842}-$ DM water level relative to the level of DM1842; Object HS - hunger stones HS1, HS2 and HS3 in Děčín (Table 4) and DZ in Dolní Žleb (Table 5); $(x)$ sources of data (P - Protokoll (1842); NS - Neue Schriften (1845); L levelling and surveying in 2015 (Table 4)); very good agreement is denoted in bold.

\section{Conclusions}

Hunger stones with low water marks are a phenomenon that has been and is regionally limited to the Upper Rhine basin and the Elbe River. In other regional areas, we have not been able to find an analogous activity where, for centuries, minimum water levels have been marked. In the Rhine basin, the water level of Lake Constance (Bodensee) and the Rhine level in the area downstream of the confluence with the Aare River to Cologne were marked. While very few of the former objects with low level marks are available in the Rhine basin, the situation is still favourable in the sandstone part of the Elbe canyon from Děčín to Pirna and its surroundings. There are at least 27 objects on the Czech side and at least 10 stones on the German side, mainly with signs dating mostly from the 20th century. Still, several of them are part of an older tradition prior to 1892 or 1842 . Of these, we can only be sure of the stones in Těchlovice, Děčín, Dolní Žleb, Hřensko and Pirna. According to the existing findings, the oldest marks from the 17th and 18th centuries have been preserved only in Děćín and Pirna, even though they used to be in several places, and we are not sure about Dolní Žleb. A number of stones on the navigation route, including the hunger stones, were recommended for blasting by navigation committees in 1842 and 1850.

The situation in Děčín and Pirna in particular is exceptional. It consists of the existence of very old records of minimum water levels and the existence of old records of water levels. In Děčín, moreover, the 590-year-old flood marks and the 490-year-old low water marks are combined in one logical complex. It is evident that the motivation for making the low water marks was related to navigation conditions in the Elbe canyon. In fact, this tradition was made possible by the availability of the local material, sandstone in the form of rocky outcrops or boulders, onto which the marks could easily be cut, engraved or painted. The minimum signs on the individual objects in Děčín are related to the dedicated water gauges and markings of the navigation depth, which was about $93 \mathrm{~cm}$ for a half load and $130 \mathrm{~cm}$ for full navigability around 1842 . The old rock water gauge for high and low water levels and its projection on the first of the three Děčín stones served the safe loading and passing, as well as the subsequent water gauge in the city.

We have shown that the years with marks or crosses are credible evidence of the occurrence of flow rate minima, mostly annual minima. If there were other minima in the year, additional lines were made, forming an occasional water gauge for the given year. Obviously, the originators' efforts were to capture the annual minimum as accurately as possible, and the guarantee of reliability was often their signature, name or initials. The marks correspond to the measured water levels of the systematic series and are relatively representative of the important minima of the Magdeburg 1727-1880 and Děčín 1851-2019 series. The correlation of the $1868,1892,1893,1904,1911,1921,1928,1930,1934$, 1947 and 1957 markings (DMs) in Děčín with the series of measurements mostly shows a match with differences of less than $4 \mathrm{~cm}$ or, exceptionally, greater. Therefore, we assume the same accuracy, i.e. compliance with real minima at the same level, for marks from the 1516-1867 period. 
Table 11. Documentation of minimum water levels in the Rhine basin according to Wittmann (1859) and of the Elbe minima on the basis of documented DMs from (a) 1303 to 1750 and (b) 1755 to 1858.

\begin{tabular}{|c|c|c|}
\hline (a) & Elbe & Rhine \\
\hline 1303 & - & Olten, Strasbourg, (W) \\
\hline 1516 & DM DZ & - \\
\hline 1517 & DM DZ & - \\
\hline 1521 & - & DM Unkelstein, (BT) \\
\hline 1536 & DM DE & \\
\hline 1541 & - & DM Laufenstein, (W) \\
\hline 1544 & DM STA (W) & - \\
\hline 1567 & - & DM Unkelstein, (BT) \\
\hline 1590 & DM RA & - \\
\hline 1615 & DM DE, Sax & - \\
\hline 1616 & DM DE, Sax & - \\
\hline 1627 & DM Sax & - \\
\hline 1631 & DM Sax & - \\
\hline 1634 & DM DZ & - \\
\hline 1635 & DM Sax & - \\
\hline 1636 & DM Sax & - \\
\hline 1637 & DM Sax & - \\
\hline 1639 & - & DM Unkelstein, (BT) \\
\hline 1654 & DM ME & $\begin{array}{l}\text { Bacharach ( } 25 \text { people stood on the Altarstein to show how much } \\
\text { the water level had decreased), (W) }\end{array}$ \\
\hline 1660 & DM Sax & - \\
\hline 1666 & DM STA, Sax & - \\
\hline 1672 & - & Olten, Staad, Konstanz (Horn), (W) \\
\hline 1678 & DM Sax & - \\
\hline 1681 & DM KO & - \\
\hline 1686 & DM Sax & - \\
\hline 1692 & - & DM Laufenstein, (W) \\
\hline 1704 & - & DM St. Goar, (W) \\
\hline 1705 & DM Sax & - \\
\hline 1706 & DM DE, PI, Sax & - \\
\hline 1707 & DM DE, PI, Sax & - \\
\hline 1718 & DM ST & - \\
\hline 1719 & DM DE & - \\
\hline 1725 & - & DM Mammern, DM Konstanz, (W) \\
\hline 1726 & DM Sax & - \\
\hline 1746 & DM DE, PI, ST & - \\
\hline 1749 & - & DM Rheinau, (W) \\
\hline 1750 & - & DM Laufenstein, Cologne bridge pillars, Bacharach, (W) \\
\hline (b) & Elbe & Rhine \\
\hline 1755 & - & DM Mannenbach, (W) \\
\hline 1761 & DM Sax, (GBS) & \\
\hline 1766 & DM DE & - \\
\hline 1767 & - & Cologne bridge pillars, $(\mathrm{W})$ \\
\hline 1782 & DM DE, PI, Sax & - \\
\hline 1785 & - & DM Mannenbach, (W) \\
\hline 1789 & DM Sax (NI), (GBS) & \\
\hline 1790 & DM DE, ST, & - \\
\hline 1792 & - & The lowest stage in Bodensee, Mammern, (W) \\
\hline 1800 & DM DE, SCH, PI, ST & The lowest stage of the Rhine in 30 years, Mainz bridge (W) \\
\hline 1811 & DM DE, PI & - \\
\hline 1823 & - & Very low water stage of the Rhine \\
\hline 1834 & DM DE, PI, ST & - \\
\hline 1835 & DM DE, PI, ST & - \\
\hline 1842 & DM DE, DZ, PI & - \\
\hline 1848 & - & DM Laufenstein, (W) \\
\hline 1858 & DM Pirna & The lowest stage of the Rhine, (W) \\
\hline
\end{tabular}


(a) DM, Elbe River

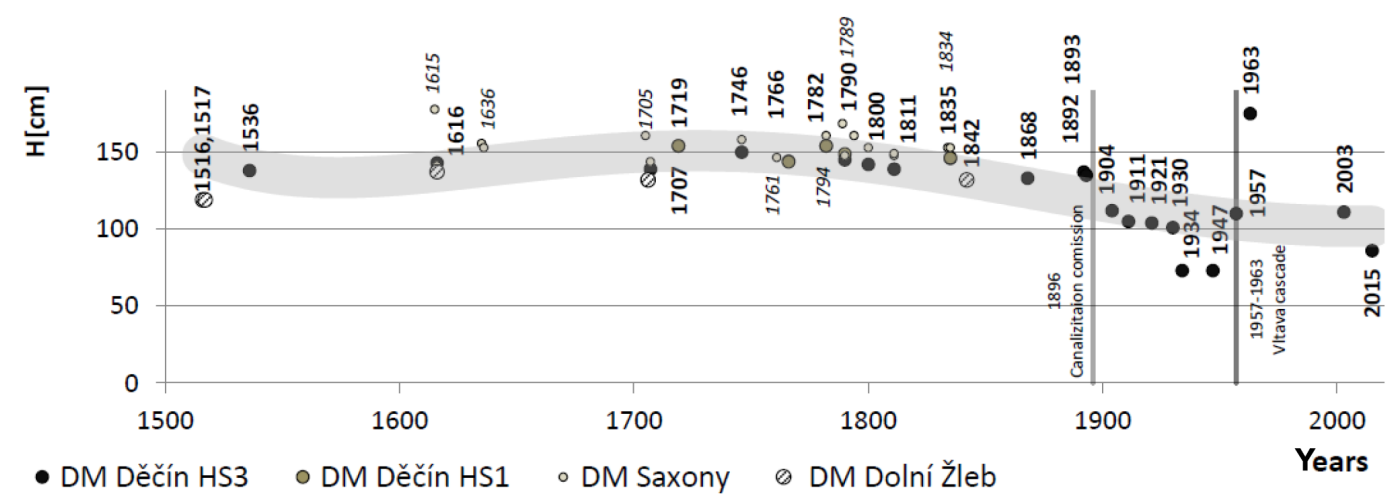

(b)

DM, Rhine River

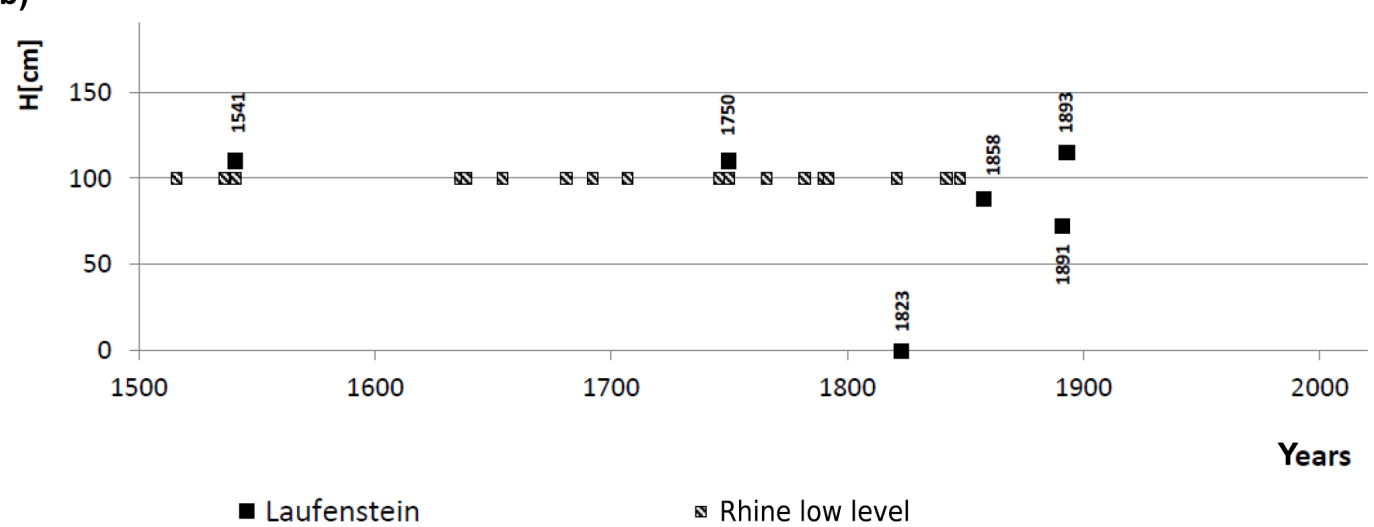

Figure 9. Graphical overview of DM data from the Czech and Saxon areas (a). The black and grey circles represent the DM minima derived from the hunger stone in Děčín, and the hatched circles relate to the stone in Dolní Žleb. This ensemble is completed by minima from the Saxon data (small circles; Table 9). The grey line highlights the trend of DM minima. Graphical overview of DM data from the Rhine basin (b). Water level minima derived from the Laufenstein DM (black squares) and other epigraphic documentation (hatched squares) (Table 11a, b).

According to the observed water level minima in the 16th and early 17 th centuries, the minima were at the same level and probably at an even lower level than in 1842. No completely reliable water level minimum marks are yet available for the Maunder Minimum (MM) period in the Czech territory. The marks of 1654 (Meissen) and 1681 (Königstein) are documented only by more remote literature, and their height is unknown. The exceptions are the marks at the end of the $\mathrm{MM}$ in 1706 and 1707. The levelling measurement of the marks on two stones and the creation of a 3D model of the Děčín stone by scanning have helped us to understand the tradition of water level recording, to rehabilitate the value of marks on hunger stones and to bring new, very reliable data on the occurrence of hydrological drought in the historical period.

However, many other questions have also emerged from the survey. The question is not whether it makes sense to document the DMs, but rather how much of the former collection remained after regulating the Elbe and operating chain-boat navigation locally. We are confident that further field and archive research will bring an opportunity to obtain valuable data on hydrological droughts of the past. The profitability of the resources and time spent on exploration and processing is evident.

Data availability. The input data used for a comparison with the data are presented in Tables 2, 4, 5 and 8. The measured records (Děčín, Dresden and Magdeburg) used in this paper are the property of the Czech Hydrometeorological Institute and are not freely available.

Author contributions. LE prepared the archive and historical sources. LE and LK prepared the field survey and measurement. TK analysed the HS object with MeshLab software, and JŠ worked 
with GIS applications and prepared maps and illustrations. All the authors participated in the interpretation of the field data and the results.

Competing interests. The authors declare that they have no conflict of interest.

Special issue statement. This article is part of the special issue "Droughts over centuries: what can documentary evidence tell us about drought variability, severity and human responses?". It is not associated with a conference.

Acknowledgements. We thank Zvonimir Dragoun for the geodetic surveying of the flood marks in 2004 and 2005 along the Elbe between Mělník and Děčín and of the low water marks later in 2015. We give sincere thanks to Oldřich Kotyza from the Litoměřice Museum for numerous friendly consultations and advice, as well as to the director of the museum in Děčín and Vlastimil Pažourek and Hana Slavíčková from the Regional Archive in Děčín for their great willingness to help and for their consultations. It is impossible to imagine our study without the hard work and interest of Randák's team from the Elbe River Administration. The friendly advice and persistent optimism and interest of Zlata Šámalová was a source of valuable information as well as energy. We also thank our colleagues from LfULG Dresden. Last but not least, we thank Václav Dvořák for the translation, Neil Macdonald and an unknown reviewer for their valuable improvements to the text, and Erin Naillon for her excellent help in proofreading the entire document.

Review statement. This paper was edited by Günter Blöschl and reviewed by Neil Macdonald and one anonymous referee.

\section{References}

Benito, G., Lang, M., Barriendos, M., Llasat, M.C., Frances, F., Ouarda, T., Thorndycraft, V., Enzel, Y., Bardossy, A., Coeur, D., Bobée, B.: Use of systematic paleoflood and historical data for the improvement of flood risk estimation. Review of scientific methods, Nat. Hazards, 31, 623-643, 2004.

Benito, G., Brázdil, R., Herget, J., and Machado, M. J.: Quantitative historical hydrology in Europe, Hydrol. Earth Syst. Sci., 19, 3517-3539, https://doi.org/10.5194/hess-19-3517-2015, 2015.

Berghaus, H.: Hydro-historische Uebersicht vom Zustande des Elbstromes innerhalb eines Hundert und achtjährigen Zeitraums von 1728 bis 1835 in Annalen der Erd-, Völker-, und Staatenkunde, Zweiter Band, Heft 5, G. Reiner, Berlin, 386-406, 1836.

Berghaus, H.: Hydrographische Beschreibung des Elbestroms in Landbuch der Mark Brandenburg und des Markgrafthums Nieder- Lausitz in der Mitte des 19. Jahrhunderts oder der geographisch-historisch-statistiche Beschreibung, Erster Band, Adolph Müller, Brandenburg, 301-326, 1854.

Brázdil, R., Dobrovolný P., Elleder, L., Kakos, V., Kotyza, O., Květoň, V., Macková, J., Štekl V., Tolasz R., and Valášek, H.: Historické a současné povodně v České republice, Masarykova Uni- verzita v Brně a Český hydrometeorologický ústav v Praze, 369, Brno, Praha, 2005.

Brázdil, R., Bělínová, M., Dobrovolný, P., Mikšovský, J., Pišoft, P., Řezníčková, L., Štěpánek, P., Valášek, H., and Zahradníček, P.: Temperature a Precipitation Fluctuations in the Czech Lands During the Instrumental Period, Masaryk University, Brno, 236, ISBN 978-80-210-6052-4, 2012.

Brázdil, R., Dobrovolný, P., Trnka, M., Kotyza, O., Řezníčková, L., Valášek, H., Zahradníček, P., and Štěpánek, P.: Droughts in the Czech Lands, 1090-2012 AD, Clim. Past, 9, 1985-2002, https://doi.org/10.5194/cp-9-1985-2013, 2013.

Brázdil, R., Trnka, M., Řezníčková, L., Balek, J., Bartošová, L., Bičík, I., Cudlín, P., Čermák, P., Dobrovolný, P., Dubrovský, M., Farda, A., Hanel, M., Hladík, J., Hlavinka, P., Janský, B., Ježík, P., Klem, K., Kocum, J., Kolář, T., Kotyza, O., Kyncl, T., Krkoška Lorencová, E., Macků, J., Mikšovský, J., Možný, M., Muzikáŕ, R., Novotný, I., Pártl, A., Pařil, P., Pokorný, R., Rybníček, M., Semerádová, D., Soukalová, E., Stachoň, Z., Štěpánek, P., Štych, P., Treml, P., Urban, O., Vačkář, D., Valášek, H., Vizina, A., Vlnas, R., Vopravil, J., Zahradníček, P., and Žalud, Z.: Sucho v českých zemích: minulost, současnost, budoucnost, centrum výzkumu globální změny, akademie věd ČR, Brno, 400, 2015.

Brázdil, R., Kiss, A., Luterbacher, J., Nash, D. J., and Řezníčková, L.: Documentary data and the study of past droughts: a global state of the art, Clim. Past, 14, 1915-1960, https://doi.org/10.5194/cp-14-1915-2018, 2018.

Brázdil, R., Demarée, G. R., Kiss, A., Dobrovolný, P., Chromá, K., Trnka, M., Dolák, L., Řezníčková, L., Zahradníček, P., Limanowka, D., and Jourdain, S.: The extreme drought of 1842 in Europe as described by both documentary data and instrumental measurements, Clim. Past, 15, 1861-1884, https://doi.org/10.5194/cp-15-1861-2019, 2019a.

Brázdil, R., Dobrovolný, P., Trnka, M., Řezníčková, L., Dolák, L., and Kotyza, O.: Extreme droughts and human responses to them: the Czech Lands in the pre-instrumental period, Clim. Past, 15, 1-24, https://doi.org/10.5194/cp-15-1-2019, 2019 b.

Bruhus, S.: Der Wasserstand der Elbe der Mulde und Elster in den Jahren 1850-1863, Zeitschrift des statistischen Bureu des Königlich Sächsischen Ministerium für Innern, 12, 135-145, 1865.

Cvrk, F.: Stavební úpravy dolního Labe do roku 1938, Sborník z konference Labe, řeka současnosti a budoucnosti, 1994, 79-83, 1994.

Delametherie, J. C.: Journal de Physique, de Chemie, d'Historie naturele et des Arts. Tome LI., J. J. Fuchs, Paris, 480 pp., 1800.

Eddy, A.: The Maunder minimum, Science, 192, 1189-1202, 1976.

Elbekarte Poříční mapa Vltavy a Labe z Prahy do Hřenska, Mapová sbírka Státního Archivu, Chodovec, inv. č. 559, sign. DX. 2, 1848.

Elbeströmbauvervaltung: Der Elbeström sein Stromgebiet und seine wichtigsten Nebenflüsse, Berlin, I.-III., Verlag von Dietrich Reimer, Berlin, 1898.

Elleder, L.: Andreas Rudolf Harlacher - zakladatel systematické hydrologie v Čechách, Meteorologické zprávy, 65, 1-12, ISSN 0026-1173, 2012.

Elleder, L.: Historical changes in frequency of extreme floods in Prague, Hydrol. Earth Syst. Sci., 19, 4307-4315, https://doi.org/10.5194/hess-19-4307-2015, 2015. 
Elleder, L.: Proxydata v hydrologii-Řada pražských průtokových kulminací 1118-1825, ČHMÚ Praha, 103 pp., ISBN 978-8087577-44-8, 2016a.

Elleder, L.: The Hunger stones: a new source for more objective identification of historical droughts, EGU General assembly, Vienna, Austria, 17-22 April 2016, EGU2016-14986, 2016b.

Elleder, L., Vlnas, R., Daňhelka, J., Ebeling, P., and Dragoun, Z.: Sucho v r. 1874 a jeho širší souvislosti in: 2020. Vybrané kapitoly z historie povodní a hydrologické služby na území ČR II., edited by: Daňhelka, J. and Elleder, L., ČHMÚ Praha, under review, 2020.

Fügner, D.: Die historische Entwicklung des hydrologischen Messwesens in Sachsen, Sonderdruck gewässerkunndliche Mitteilungen, Heft 5/6, 156-160, 1990.

Fügner, D. and Schirpke, H.: Neue Ergebnisse der Hochwasserberechnung für den Elbestrom in Dresden, WasserwirtschaftWassetechnik, 8, 189-191, 1984.

Hanel, M., Rakovec, O., Markonis, Y., Máca, P., Samaniego, L., Kyselý, J., and Kumar, R.: Revisiting the recent European droughts from a long-term perspective, Sci. Rep.-UK, 8, 949911, https://doi.org/10.1038/s41598-018-27464-4, 2018.

Harlacher, A. R.: Bestimmung der Wassermenge von Flüssen etc., Technische Blätter Zur Hydrographie Böhmens III. roč, 1871, Deutsche Polytechnische Verein, 137-184, 1871.

Harlacher, A. R.: Zur Hydrographie Böhmens, Technische Blätter III, 1871 Deutsche Polytechnische Verein, 81-112, 1872.

Harlacher, A. R.: Hydrometrické práce na Labi u Děčína. (Hydrometric measurements in Elbe River by Děčín), Hydrografická komise království českého, Praha, 24 pp., 1883.

Hofmann, F. W.: Chronik der Stadt Magdeburg, Dritter Band, Verlag Emil Baensch, Magdeburg, 555 pp., 1850.

Jenč, P., Peša, V., and Barus, M.: Dokumentace skalních rytin, nápisů a dalších prvků historické krajiny v CHKO Český ráj, část Maloskalská Drábovna a Besedické skály - Kalich. Zpráva pro Geopark Český ráj o. p. s., Vlastivědné muzeum a galerie v České Lípě a Správa CHKO Český ráj Turnov, 2008.

Faulhaber, P.: Veränderung hydraulisch-morphologischer $\mathrm{Pa}$ rameter der Elbe, Mitteilungsblatt der Bundesanstalt für Wasserbau, 82, available at: https://izw.baw.de/publikationen/ mitteilungsblaetter/0/faulhaber.pdf (last access: 2 July 2020), 2000.

Faulhaber, P.: Niedrigwasserereignisse an der Elbe und ihre Bedeutung für den Ausbau des Flusses, Bundesanstalt für Gewässerkunde Veranstaltungen 1, available at: https://www. bafg.de/DE/05_Wissen/04_Pub/03_Veranst/201301.pdf (last access: 2 July 2020), 2013.

Focke, F.: Aus dem ältesten Geschichts-Gebiete Deutsch-Böhmens. Eine geschichtliche Durchforschung des Elbe- und Eulau-Thales samt Umgebung (and der sächsischen Gränze) von frühester Zeit bis in die Gegenwart. II. Band. Im Selbstverlage des Verfassers, Varnsdorf, 410 pp., 1879.

Frölich-Schauseil, A.: Von Schandau in der Sächsischen Schweiz bis zur Sandbänken in der Nordsee, in: Die Elbe, über dem Wandel eines Flusses vom Wiener Kongress (1815) bis zu Gegenwart, edited by: Martin, A. and Fischer, N., Schriften zur Sächsischen Geschichte und Volkskunde, 58, 205-225, 2018.

Krolmus, V.: Kronyka čili dějepis všech povodní posloupných let, suchých i mokrých, úrodných a neúrodných na obilí, ovoce a vína, hladů, morů a jiných pohrom v Království Českém, Praha, 261 pp., 1845.

Mikšovský, J., Brázdil, R., Trnka, M., and Pišoft, P.: Long-term variability of drought indices in the Czech Lands and effects of external forcings and large-scale climate variability modes, Clim. Past, 15, 827-847, https://doi.org/10.5194/cp-15827-2019, 2019.

Merian, M.: Topographia Palatinus Rheni et Vicinarum Regionum, Frankfurt am Main, 105 pp., 1645.

Novotný, J.: Dvě stoleté hydrologické řady průtokové na českých řekách. Sborník prací Hydrometeorologického ústavu Československé socialistické republiky, 2, Praha, 116 pp., 1963.

Neue Schriften: Neue Schriften der Kaiserl., Königl. Patriotischen ökonomischen Geselschaft im Königreich Böhmen, vol. 9, 1845.

Ogurtsov, M. G.: Deep minima of the Sun's activity according to data of solar paleoastrophysics, Deep minima of the Sun's activity according to data of solar paleoastrophysics, Journal of Physics: Conference Series 1400, Conf. Ser. 1400 022048, 2019.

Old hydrometry: The archive of old hydrometric measurements by hydrological service in Prague in 1877-1940 years, Archive of CHMI, manuscript, 1877-1940.

Pažourek, V.: Lodní doprava a hladový kámen v Děčíně, Děčín vlastivědné zprávy 2-IV, 45-52, 1995.

Pekař, J.: Kniha o Kosti, ISBN 80-902353-3-6, 367, 1998.

Pfister, C.: Überschwemmungen und Niedrigwasser im Einzugsgebiet des Rheins 1500-2000. Der Rhein-Lebensadereiner Region, Bern, 265-273, 2006.

Pötzsch, C. G.: Chronologische Geschichte der grossen Wasserfluthen des Elbstroms, Walther, Dresden, 232 pp., 1784.

Protokoll: Protokoll der von den hohen Elbeuferstaaten abgeordneten, in eine Kommission vereinigten Wasserbauverständigen zur Erledigung der vorkommenden hydrotechnischen Fragen der in Folge Artikel XXX. der Elbeschifffahrtacte in Dresden versammelten den Revisions-Kommission, Dresden, 267 pp., 1842.

Protokoll: Verhandlungen Elbestromschau Commission der betreffenden Uferstaaten über die Schifbarkeit der Elbe und deren Verbesserung, Hamburg, 167 pp., 1850.

Protokoll: Verhandlungen Elbestromschau Commission der betreffenden Uferstaaten über die Schifbarkeit der Elbe und deren Verbesserung. Hamburg, 101 pp., 1858.

Randák, P.: Hladové kameny Dolní Žleb \& Těchlovice, Povodí Labe, státní podnik, závod Roudnice nad Labem, available at: http://www.pla.cz/ (last access: 2 July 2020), 20 pp., 2015.

Randák, P.: Hladové kameny v Dolním Žlebu a Těchlovicích in Minulostí Českého Švýcarska IX, 5-17, 2017a.

Randák, P.: Hladové kameny Hřensko, Povodí Labe, státní podnik závod Roudnice nad Labem, available at: http://www.pla.cz/ (last access: 2 July 2020), 19 pp., 2017 b.

Reuter: Die Abnahme des Wasserstandes der Flüsse und die Versandung ihrer Betten hängen von der Verminderung und zu starken Lichtung der Gebürgswaldungen ab, Zeitschrift für den Forst und Jagdwesen mit besondere Rücksicht auf Bayern, 11 Band, 2. Heft, 28-87, 1840.

Schattkowsky, M.: Die Familie von Bünau: Adelsherrschaften in Sachsen und Böhmen vom Mittelalter bis zur Neuzeit, Leipzig, 532 pp., 2003.

Shahin, M. M. A.: Hydrology of the Nile Basin, Amsterodam, New York, Oxford, Tokyo, 574 pp., 1985. 
Shamir, E., Ben-Moshe, L., Ronen, A., Grodek, T., Enzel, Y., Georgakakos, K. P., and Morin, E.: Geomorphology-based index for detecting minimal flood stages in arid alluvial streams, Hydrol. Earth Syst. Sci., 17, 1021-1034, https://doi.org/10.5194/hess-171021-2013, 2013.

Schulte, L., Schillereff, D., and Santisteban, J. I.: Pluridisciplinary analysis and multi-archive reconstruction of paleofloods: Societal demand, challenges and progress, Gloplacha, 177, 225-238, 2019.

Simon, M.: Untersuchungen zu anthropogenen Beeinträchtigungen der Wasserstände am Pegel Magderburg- Strombrücke, PIK Report 116, 42 pp., Potsdam, 2010.

SLČ: Staří letopisové čeští od roku 1378 do 1527, čili pokračování v kronikách Přibíka Pulkavy a Beneše $\mathrm{z}$ Hořovic z rukopisů starých vydané, Ed. Palacký, 1941.

Ursinus, J. F.: Collektania zur Geschichte der Stadt und des Landes Meißen, Praha, 1790.

Van Loon, A. F.: Hydrological drought explained, WIREs Water 2015, 2, 359-392., https://doi.org/10.1002/wat2.1085, 2015.

Velímský, T.: Město na louce: archeologický výzkum na Mariánské louce v Děčíně 1984-1989, Děčín: Okresní muzeum, ISBN: 8085036-05-3, 54, 1991.

von Berg, D.: Veränderung des Wasserstandes der Flüsse und ihre Ursachen, Kritische Blätter für Forst und Jagwirtschaft, 50, 158$191,1867$.

Walter, H.: Über die Stromschnelle von Laufenburg, Diss. Phil. II, Zürich, Switzerland, 1901.

Walther, P. , Büttig S., Kaltofen, A., Kaden, M, and Lange J. M.: Erfassung der Hungersteine in der Elbe, Sächsische Landesamt für Umwelt, Landwirtschaft und Geologie, Archäologische Gesellschaft in Sachsen, Senckenberg Naturhistorische Sammlungen Dresden, available at: https://www.thueringen.de/mam/th8/tlug/content/abt_1/v_ material/2019/lange_hungersteine_untiefen.pdf (last access: 2 July 2020), 2018.
Weikinn, C.: Quellentexe zur Witterungsgeschichte Europas von der Zeitwende bis zum Jahr 1850, I. (Hydrgraphie (1751-1800), edited by: Börngen, M., 673 pp., 2000.

Wetter, O., Pfister, Ch., Werner, J., P., Zorita, E., Wagner, S., Seneviratne, S., I., Herget, J., Grünewald, U., Luterbacher, J., Alcoforado, M., J., Barriendos, M. Bieber, U. Brázdil, R. Burmeister, K., H., Camenisch, Ch., Contino, A., Dobrovolný, P., Glaser, R., Himmelsbach, I., Kiss, A., Kotyza, O. Labbé, T., Limanówka, D., Litzenburger, L., Nordl, Ø., Pribyl, K., Retsö, D., Riemann, D., Rohr, Ch. Siegfried, W., Söderberg, J., and Spring, J.-S.: The year-long unprecedented European heat and drought of 1540 - a worst case, Climate Change, 125, 349-363, 2014.

Wex, G.: Ueber die Wasserabnahme in den Quellen, Flüssen und Strömen, Zeitschrift des Oesterreichischen Ingenieur und Architekten Vereins, 25, 63-76, 1873.

Wilhelm, B., Ballesteros Cánovas, J., A., Macdonald, N. Toonen, W., H., J. , Baker, V., Barriendos, M., Benito, G., Brauer, A., Corella , J. P., Denniston , R., Glaser , R., Ionita, M., Kahle, M., Liu, T., Luetscher, M., Macklin, M., Mudelsee, M., Munoz, S., Schulte, L. St. George, S., Stoffel, M., and Wetter, O.: Interpreting historical, botanical, and geological evidence to aid preparations for future floods, WIREs Water, 6, e1318, https://doi.org/10.1002/wat2.1318, 2019.

Wittmann, J.: Chronik der niedrigsten Wasserstände der Rhein, Seifert, Mainz, 142 pp., 1859.

Wiesenfeld, K.: Andenken an der dritten Versammlung deutschen Architekten und Ingenieure in Prag, im Jahre 1844, Allgemeine Bauzeitung, 251-261, 1844. 